University of South Florida

DIGITAL COMMONS

@ UNIVERSITY OF SOUTH FLORIDA
Digital Commons @ University of

South Florida

$7-1-2002$

\title{
Conditions that Promote Creativity at Public Transit Agencies
}

CUTR

Follow this and additional works at: https://digitalcommons.usf.edu/cutr_nctr

\section{Scholar Commons Citation}

CUTR, "Conditions that Promote Creativity at Public Transit Agencies" (2002). Research Reports. 190.

https://digitalcommons.usf.edu/cutr_nctr/190

This Technical Report is brought to you for free and open access by the National Center for Transit Research (NCTR) Archive (2000-2020) at Digital Commons @ University of South Florida. It has been accepted for inclusion in Research Reports by an authorized administrator of Digital Commons @ University of South Florida. For more information, please contact digitalcommons@usf.edu. 


\begin{tabular}{|c|}
\hline Conditions that \\
Promote Creativity at \\
Public Transit Agencies \\
\hline
\end{tabular}




\section{CONDITIONS THAT PROMOTE CREATIVITY AT PUBLIC TRANSIT AGENCIES}

\section{INTRODUCTION}

In 1997, the National Urban Transit Institute at CUTR produced a report entitled "Lessons Learned in Transit Efficiencies, Revenue Generation, and Cost Reductions." That report summarized over 175 different methods being used at transit agencies to make additional revenue and save money, without losing passengers. Information that was included in the report was gained by surveying transit agencies to find out the more creative or unusual ways that they were earning new revenues or cutting costs. The report was very well received in the transit industry, with findings presented at three national conferences and one state conference. In addition, the Research and Special Programs Administration of USDOT received requests for many hundreds of copies of the report from transit agencies throughout the country. The "Lessons Learned" report provided extremely useful information and ideas that transit agencies could put into practice immediately.

What was striking to the author was that a handful of the 55 agencies that responded to that project's survey stood out from the rest in terms of their creativity in developing ways to supplement their budget. Their returned surveys reflected a very distinct "attitude" that was genuinely refreshing. The author determined that there might be a great deal to learn by doing case studies of the agencies that appeared to be particularly creative. He hoped to learn more than just "what" the transit agencies were doing to make and save money; he hoped to learn "how" they became so creative.

This report is intended to identify the environment, conditions, and practices that contributed to the creativity that was present in these transit agencies in the hopes that further lessons can be learned that can also be replicated by other transit managers.

This report required site visits to the four transit agencies that demonstrated such high levels of creativity. The author spent a day at each of the transit agencies to conduct interviews with as many of the staff as possible to gain insights on how they approached their responsibilities. Appendix A identifies the representatives interviewed by the author. Appendix B provides a summary of the more creative techniques that these agencies were using to generate new revenues and cut costs. 
This report provides a brief summary of the site visits and more importantly, categorizes the traits and management practices that contributed to the agencies' distinctive performance. It should be noted that these site visits were conducted in late 1999 and 2000. The General Managers of three of the four transit agencies have changed since that time. This report reflects the conditions as they existed at the time of the site visits. 


\section{SUMMARY FINDINGS FROM SITE VISITS}

\section{Central New York Regional Transportation Authority (Centro)}

\section{"A leader is a dealer in hope." Napoleon Bonaparte}

\section{Environment and Conditions}

Centro is the agency that provides public transit services to the greater Syracuse area of upstate New York. The agency has approximately 500 employees that provide fixed route and paratransit services with a fleet of slightly more than 200 vehicles. Greater Syracuse is reflective of middle class America and is regarded by the transit staff as a relatively conservative area that is slow to change. In fact, Proctor and Gamble uses the city as its test ground for new products. The company believes that if the population of Syracuse accepts a test product, that product will also be profitably marketable throughout the United States.

The Syracuse area did not enjoy the benefits of the booming national economy in the 1990s. An article in the New York Times (“As U.S. Economy Races Along, Upstate New York is Sputtering”) written in 1997 described Syracuse as one of the worst areas in New York in terms of growth and economic development. While the region surrounding the city has maintained its population base of approximately 500,000, the central city of Syracuse has lost population on a steady basis over the past 30 years. This has made it difficult for the transit agency to remain competitive, as its core service area loses population.

Centro's Board of Directors is comprised of seven members, none of whom are elected officials. The governor of New York appoints all members, with four being nominated by Onondaga County, and three by the City of Syracuse. Most of the members of the Board are 60 years of age or older, and reflect the conservative values of their community. According to the General Manager, the Board members generally regarded Centro as "the bus company" that primarily served a social service function. They took their responsibilities of oversight very seriously, but their singular concern was to make sure that the bus service was reliable, safe, and timely for transit dependent people. The Board did not discourage new initiatives, but they would approve staff to do new things only as long as it didn't result in costs that would ultimately decrease service to the public. For instance, the Board did not discourage the staff's recommendation to change the fleet to use compressed natural gas, but only approved it after assurances that such a change would not add to the agency's 
budget or threaten the reliability and amount of bus service expected by the public.

The general environment and conditions in the greater Syracuse area would not lead one to expect that Centro would be a hotbed for transit creativity. However, at least two factors played a major role in making it so. First, Centro suffered a triple financial catastrophe in the 1990s. Reductions in federal operating assistance caused the agency to lose approximately $\$ 1.2$ million in annual operating revenues. At the same time, the greater Syracuse area experienced a recession. The population of the city decreased from 180,000 to 158,000 . This sudden loss of population from the core of Centro's service area contributed to a reduction in ridership and farebox revenue. Perhaps worst of all, the primary source of local operating assistance also was affected by the area's recession and shrinking population. Centro had been receiving $\$ 4.6$ million per year from the city's mortgage recording tax. Due to the reductions in home sales, Centro's revenue from this source decreased to $\$ 2.5$ million per year. Within two years, Centro had lost almost $\$ 4$ million in expected revenue in a \$24 million annual budget. These conditions clearly prompted a need for the agency to scramble for new sources of revenue.

Centro went through some difficult times as they addressed their revenue deficits. Salaried staff was reduced from 75 to 59 . "Casual Fridays" became known as "Casualty Fridays", being the days when employees (after extensive counseling and assistance) were laid off as part of the cost reduction efforts. Service hours were reduced by approximately 20 percent.

Given the state of the local economy, the generally conservative nature of the area, and the tremendous tax burdens already in place, Centro knew it could not expect any new local sources of tax-generated revenue.

\section{Leadership}

As noted earlier, there were two major factors that helped Centro become an agency distinguished for its creativity. Partial credit can be given to the difficult financial conditions the agency found itself in, whereby necessity no doubt helped to become the mother of invention. However, the second factor that played perhaps a more important role in Centro's creativity was the character of the General Manager, Joe Calabrese. Mr. Calabrese had worked at Centro after graduating from college, but then left the agency to work in the private sector. Imbued with an entrepreneurial spirit, Mr. Calabrese created a company (Metrovision) that provided electronic information services to rail passengers. The company prospered and went public, but its founder did not want to move to New York City as was required under the new corporate structure. Mr. Calabrese then rejoined the public sector as the General Manager of Centro, but he brought private sector management principles and a pioneering spirit with him. 
Centro became extremely creative in generating new revenues. Some of this was due to a pledge to the community to do everything possible before reducing transit service. In addition, the agency knew that they would need to demonstrate that they were good stewards of public funds if they hoped to get any additional support from any level of government. But much of the new creative effort was due to the General Manager's entrepreneurial approach to problems and opportunities. Among the principles that Mr. Calabrese exercised was a belief that "Anything is possible" and that an agency should "Act quickly or the competition will beat you to it". $\mathrm{He}$ believed that it wasn't necessarily large entities that devoured smaller ones; he noted that it is the quick entities that overtake the slower ones. His general philosophy is to "Never say never" and always ask, "Why can't we?" In short, nothing was off limits. This approach was partially based on the necessity of the agency's budgetary circumstances, but also on the General Manager's character that combined aggressiveness, curiosity, and love for a challenge.

\section{"Let's try. . . it could be fun." Joe Calabrese, General Manager}

As Centro's marketing manager Dave Ristau noted, the General Manager was not bound to traditional public sector management paradigms. He wanted people to be results oriented rather than process oriented. $\mathrm{Mr}$. Calabrese believed that people were not born as bureaucrats - he believed that people probably want to do things differently. However, many people, particularly in government, have been conditioned to perform in process-oriented ways that are within traditional comfort zones that involve little risk. Mr. Calabrese stated, "The job of leadership is to take people where they ordinarily would not go." Hence, he encouraged his employees to "Take a chill pill" and not worry so much about the consequences of new techniques. He backed that up by assuring them that there would be no penalty for first time failures of new attempts to improve service and agency efficiency. Mr. Calabrese believed that providing his staff with a certain amount of "cover" was one of his primary responsibilities as General Manager. He always wanted to test new ideas. "Let's try - it could be fun," was one of his mottos.

\section{"We're retail! We regard every bus as a 7-11 store." Craig Williams, Human Resources Director}

This philosophy had obviously reached the ranks of directors, all of who knew they had to think outside the box in order to generate new revenues for the agency. As one director stated, "We're retail! We regard every bus as a 7-11 store." What this meant was that each manager had looked at their areas of responsibility to determine what resources they had that could be of value to someone else in the community. This would then result not only in additional revenue; 
Centro's value as a community asset would also be enhanced.

One other philosophy that Mr. Calabrese emphasized was the importance of customer service. As was stated earlier, Centro's Board of Directors had always taken its responsibility to provide quality service seriously. However, based on $\mathrm{Mr}$. Calabrese's background in the private sector and his emphasis on marketing principles, a "Customer First Award" was established to recognize employees that went above and beyond normal expectations in helping or serving customers of Centro. For instance, one of the rewards given that year went to two bus operators who gave a surprise birthday party for a passenger on a bus. The operators received $\$ 100$ and were recognized by the Board of Directors. This type of award helped to emphasize that the customer came first at Centro, and that their employees should always be trying to do things in the interest of their passengers. The emphasis on passengers and customers helped to direct internal staff actions in positive external directions, rather than internal bureaucratic concerns.

\section{Personnel and Personal Matters}

Mr. Calabrese understood that management involves getting things done through other people, and whom those other people are is obviously critical to the success of an agency. It is also instrumental in determining the level of creativity that an agency enjoys. Mr. Calabrese preferred to fill vacancies with people not only from outside the agency, but from outside the transit industry as well. He firmly believed that new blood was good for the transit industry. The fresh perspective that such new people could bring was more important than ensuring upward mobility opportunities for employees within the organization. All of the middle management personnel who had been hired the two years previous to this project's site visit had come from non-transit backgrounds. The general manager's belief was that their out-of-transit experience would add to the creative activity within the agency.

In addition, Mr. Calabrese advised the directors to hire people that would seem fun to work with. The agency stressed finding people with customer service orientation, good interpersonal skills, and good communications capabilities. Centro's manager of paratransit services, Linda McKeown, noted that she had been advised that, when hiring new people, her job was "to hire the next president of the company." She noted that she often looked to hire people from the banking industry who were thorough in their work, but also experienced in working with people. Her belief was that most new employees could be taught the technical stuff associated with their new jobs, but you can't change the basic behavior and attitude of people. Hence, it was important to hire people who were very tolerant of other people and new ideas. The Director of Operations was also committed to finding the most suitable applicants possible for any new bus operators 
vacancies. Centro utilized the Bus Operator Selection System in order to help identify the bus operator candidates with the best aptitude for customer service and working with other people.

All of the directors were actively engaged in professional development. Virtually all of the directors attended state transit association meetings twice a year and were active members of "users groups" within their own discipline. They talked with their counterparts around the country, either on the telephone, or via email. They were plugged into the American Public Transit Association as well. In addition, many of them were members of Transportation Research Bureau committees. In short, professional development at Centro was encouraged and engaged in by most transit managers. They realized that creativity can often be spurred by exposure to the activities taking place in other transit agencies, and readily admitted stealing every good idea they came across.

Centro also held annual brainstorming sessions, but rather than call them "retreats", these sessions were referred to as "Forwards". Mr. Calabrese preferred not to use a term that implied the agency was going backwards. He wanted people to think positively at all times and to focus on what the agency's role could be in the community.
While it might seem like a simple thing, Centro modified the dress code for staff to business casual before it became more popular nationwide. Paratransit Services manager Linda McKeown believed that this made a significant difference that helped ideas flow more smoothly in the organization. She believed that the more comfortable people were, the more they were likely to share ideas with each other. There was far less competition among women in the agency on how they looked, and more emphasis on ideas.

Finally, Mr. Calabrese realized that Centro's staff had to establish relationships within the community that were based on more than just their official positions. If they were to be able to identify how the transit agency could become more than it was, agency staff would need to be in direct touch with the actions of many community groups. $\mathrm{He}$

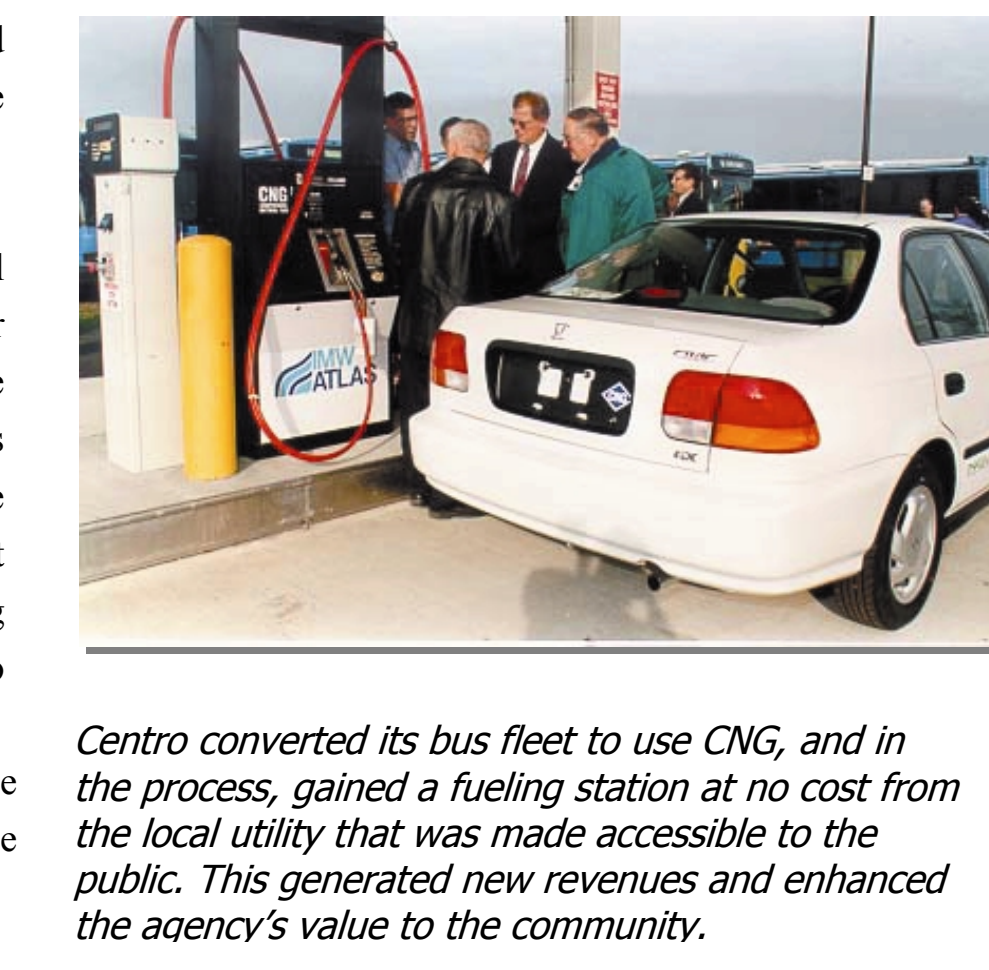


wanted his staff, including himself, to be members of various community groups and to attend social functions, and to be mindful of the need to create a kinder, friendlier image of Centro. He believed personal connections were necessary if the agency wanted to gain trust within the community. He also suggested that community groups are less likely to crucify public managers if they know them as people rather than just bureaucrats.

Many in the agency, including new Marketing Manager Dave Ristau (whose experience was also in the private sector) felt that Centro had lost contact with its community to the point where it had become a non-factor in the region. He worked hard to establish a Citizens Advisory Board that helped to define the greatest needs in the community and how Centro could contribute to improving conditions in the region. $\mathrm{He}$

also worked extensively with the local media to explain the various actions Centro was taking to earn extra revenue and provide resources to the community that went beyond the mere transporting of people. Mr. Ristau understood that getting the media on the agency's side was also a way of gaining the confidence of Centro's relatively conservative Board of Directors. With positive stories being told by the press, the Board was more likely to grant the staff the freedom to do new, non-traditional activities.

\section{Organizational Structure, Practices, and Philosophies}

Mr. Calabrese preferred a looser, less structured environment. He thrived on a bit of chaos. To reflect this organizationally, the General Manager modified the organization chart. Centro had

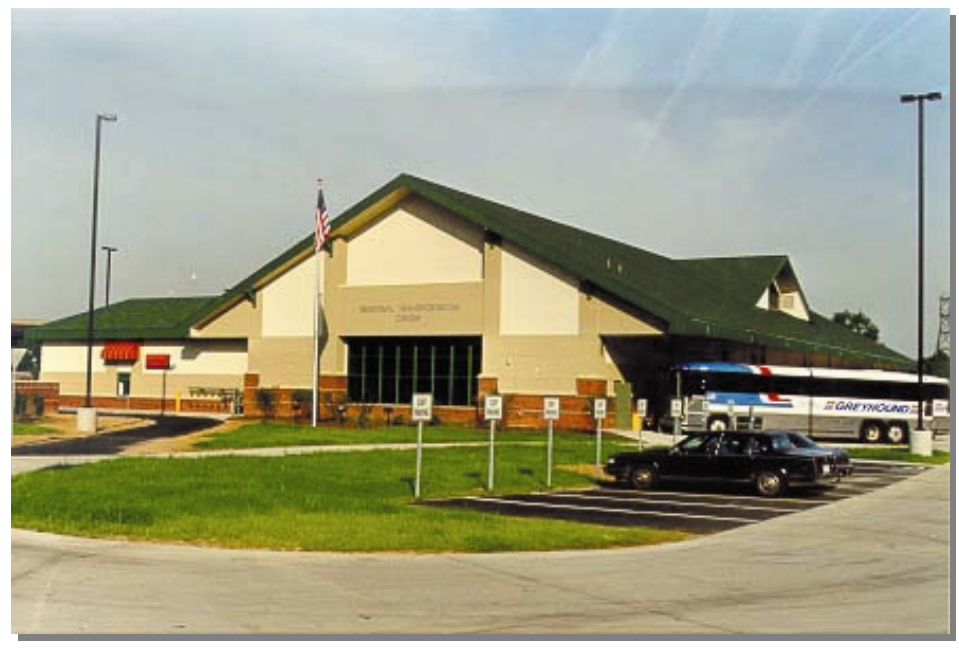

Centro's new intermodal center was promoted as not just a transportation facility, but also as a contributor to economic development in a financially-challenged city. previously been relatively top heavy, with a President, then a General Manager, then an Assistant General Manager, whom all division heads reported to. Mr. Calabrese flattened the organization by eliminating the president and Assistant General Manager positions, and had all division directors report directly to him. $\mathrm{He}$ required all directors to create new standards and to strive to solve problems, not just manage them. Every manager was responsible for developing 
"Key End Results" that were specific and measurable objectives. Every manager was held accountable for accomplishing these objectives. Managers at Centro also knew that times were tough in the agency, and they truly believed that if they couldn't "cut it" (make distinct progress on their key end results), they would be replaced by someone who could. However, they also knew they had the support of a director who wanted to try new techniques and was always interested in learning new things.

Although there was a positive tension among the individual managers to attain their key end results, many of them believed that the relatively small size of the agency was conducive to more interaction and teamwork. The flatter organization tended to force solutions to come from the bottom and middle of the organization, rather than from the top. Planning Director Rich Landerin noted that there was a good deal of cross-fertilization, and that everyone at the agency did more than one job. No one was allowed to ever say, "That's not my job". Buzzwords such as "empowerment" were never used, but once a problem of any kind was discovered by anyone, regardless of what department it affected, that problem "belonged" to him or her until it was solved.

Each Monday the team of directors would meet to "review the game film" from the previous week and identify the major objectives for the near future. Many of the managers had been at the agency for 18 years, and some were more risk-averse than others. For some there was also a tendency to be less enthusiastic about changing some practices that they had put into place and were quite proud of. But as one old saying notes, even a beautiful flag lies limp without a breeze to stir it. Mr. Calabrese provided the breeze, and, for the most part, there appeared to be a friendly competition for managers to try to top one another.

The agency did not rely on bonuses to stimulate managers' creativity. There was a general recognition that the public would not be supportive of bonuses, and that the media would be unforgiving no matter how deserving employees might be. All managers were eligible for five percent raises each year and were rewarded based on their progress on their key end results. What did seem to excite most of the managers was the emphasis on managing this public agency differently and in a way that broke the traditional mold of the agency in the community. Centro's managers clearly understood the importance of providing quality transit service to their most frequent customers. However, they felt they had to change their image as an agency that existed only to serve the less fortunate and dependent. As one manager noted, that type of approach can be depressing and limiting, and make them feel less than vital. Another manager noted that one's self-image suffers when you only deal with the disenfranchised. 
"We are in the 'transformation' business, not just the

transportation business.

We are trying to transform lives

and communities."

Craig Williams

Centro's Mission Statement acknowledged the primary function of the agency, but also reflected a concern with the environment and a desire to go beyond their primary function:

\section{"The mission of the Central New}

York Transportation Authority is

to be responsive to the

transportation needs of the

central New York community by

providing services which are

safe, clean, reliable, and

environmentally responsible with

a goal of maximizing the

taxpayers return on investment."

Centro's Human Resources Director, Craig Williams said, "I'm here not because of what we have been, but because of what we can be." An increasing number of managers wanted Centro to become a meaningful partner in economic development that the community desperately needed. $\mathrm{He}$ and others on the staff wanted the agency to become regarded as a true public benefit corporation. They wanted to know what value they could add to the community. What were they doing that someone else in the area could benefit from? They wanted the agency to become regarded as a community asset, not a liability, to match their agency's skills and resources with the community's needs. They believed that whatever they did had to have an application beyond Centro's four walls. As Mr. Williams enthusiastically stated, "Transportation is only a means to an end. We are in the transformation business, not just the transportation business. We want to help transform lives and communities."

\section{Notable Results}

Many of the creative techniques that were instituted at Centro would have been started regardless of the agency's budgetary circumstances due to the philosophy of its top managers. However, their strategy to reconnect with the community and demonstrate their efforts to maximize efficiency also paid off in financial support from the State of New York. Even though some of the creative techniques instituted brought in relatively small amounts of new revenue, Centro was able to demonstrate to the governor that the agency was doing everything it possibly could to economize and maximize its revenue potential. Members of the media had also told the General Manager that it was about time the agency started managing and stopped begging. Based largely on being able to demonstrate this, Centro received three years of emergency supplemental funding averaging approximately $\$ 1$ million annually from the State Legislature. They 
were the only transit agency in upstate New York to receive such allocations, even though other urban areas were suffering similar difficult budget difficulties. 


\section{Washoe County Regional Transportation Commission (RTC)}

\section{"Nature abhors a vacuum." Celia Kupersmith, Executive Director}

\section{Environment and Conditions}

"Citifare" is the name given to the agency that provides transit service in Washoe County, Nevada that includes the cities of Reno and Sparks. Located on the western border of the state near Lake Tahoe, this agency is only one part of a more comprehensive organization known as the Washoe County Regional Transportation Commission (RTC). The RTC is responsible for the planning and construction of regional roads, the provision of transit and paratransit services, and also serves as the Metropolitan Planning Organization for the area. The RTC is multimodal and interdisciplinary, and serves almost as a mini-DOT in the region, which has a population of approximately 300,000 . Hence, the staff of the RTC cannot focus only on transit; they must balance the needs for highways, transit, and other alternative forms of transportation. While some transit agencies talk of becoming mobility managers, the RTC staff truly are full mobility managers. They don't fight for funds for transit in front of the MPO - they are the MPO.

Citifare's service area is perhaps best known for the City of Reno, billed as "The Biggest Little City in the World". The "gaming industry" (casinos) constitutes a substantial segment of the economy, and the area operates on a 24-hour basis. Although Citifare operates only 52 buses in peak service, the agency carries over eight million

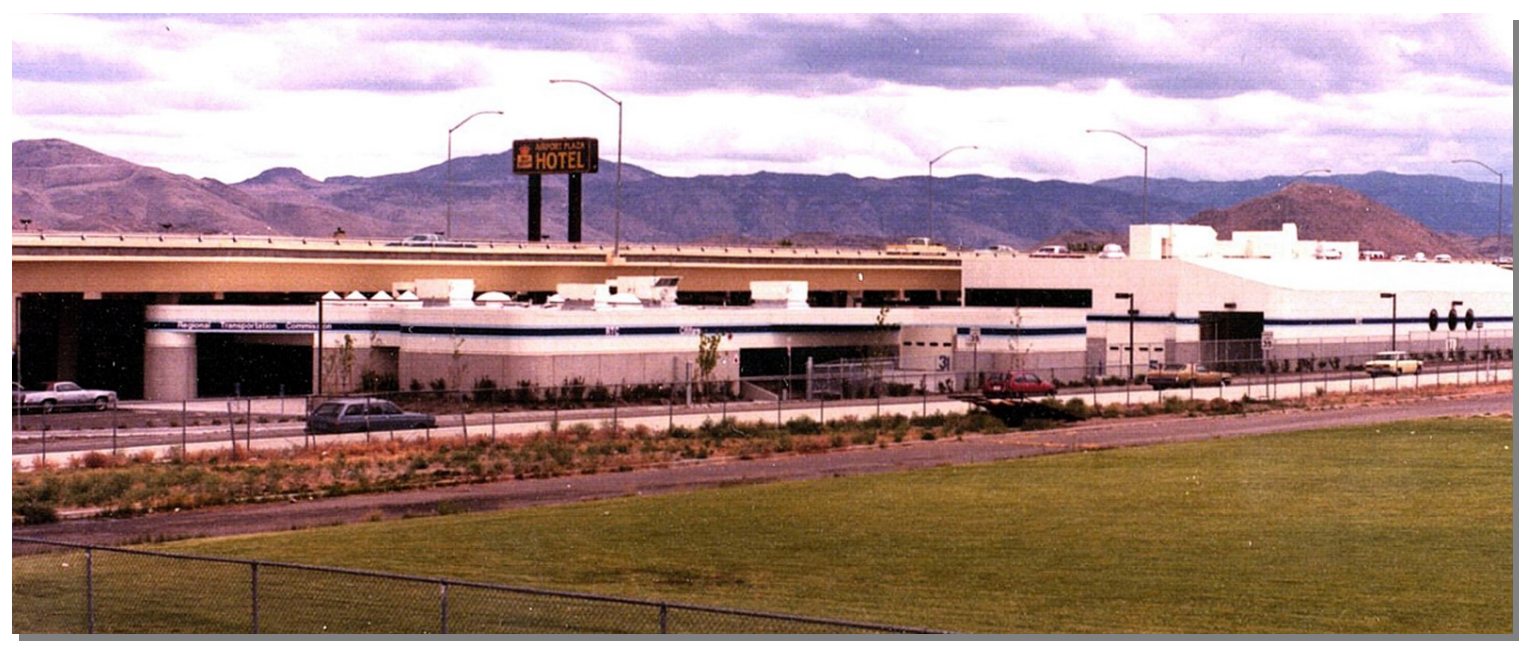

The RTC facilities, tucked under an elevated interstate highway, reflect the agency's emphasis on efficiency. 
passengers a year and enjoys a 40 percent farebox return ratio. There are thousands of casino workers and maintenance personnel who utilize Citifare as their primary means of transportation.

It should be noted that there is also a long history and expectation of excellence at the RTC. The agency has always demonstrated a strong sense of professionalism. The staff of the RTC, rather than the state DOT or the County, are regarded as the leaders and experts in transportation in the region. The RTC Commissioners are very supportive of professional development for their staff. As one staff member noted, the commissioners are primarily accountable to their own constituencies and jurisdictions, and don't have the time or inclination to micromanage the staff. The Commission expects the agency to operate like a business and to pay attention to every single penny. According to one staff member, this philosophy is consistent with the casinos' practices of counting every cent. The mission statement of the RTC is very direct and reflects the agency's emphasis on quality:

\section{"The Regional Transportation}

Commission provides leadership,

vision, public policy

development, and quality

transportation systems through a

commitment to excellence and

pursuit of goals and objectives

which meet the community's

present and future needs."
The RTC Board of Directors is comprised of five elected officials. Two of the Board members represent Washoe County, two represent the City of Reno, and one represents the City of Sparks. RTC staff noted that the cities and the county often have a hard time working together on public policy issues, but things are different at the RTC. Commissioners act in a true sense of partnership and common mission as a regional board.

As is the case in many western states, there is a strong sense of independence and great value placed in self-reliance in Washoe County. It is a conservative area where people generally believe that less government is better government. The Commission does not regard itself as a provider of social services. Many transit agencies in the United States focus on defining and furthering the quality of life in their communities. In Washoe County, there is a great acceptance of the role transit plays in the community, but the RTC's primary interest is in efficiency. The emphasis on efficiency is symbolized by the RTC headquarters facility that is compactly built underneath an interstate highway overpass. The fact that the transit function, roadbuilding function, and the MPO are all part of one agency with one staff (requiring only one director, one purchasing director, etc.) is another demonstration of the desire for economizing in the cost of government. The staff of the RTC does not concern itself with social policy and equity issues as much as it does with efficiency. This environment certainly helps spur the agency to do more 
creative things in support of the goal of generating new revenues and cutting costs.

While the region enjoys steady growth, the economy slumped in the mid-1990s. Citifare had projected a 6 percent growth in sales tax revenues, but the slow down in the economy produced only a one percent growth in such revenues. Federal transit operating assistance was being phased out as well. These developments, coupled with the region's conservative nature, created pressure on Citifare to produce even further efficiencies and productivity.

\section{Leadership}

Celia Kupersmith became the Director of the RTC in late 1993. She had worked as the Assistant General Manager for Development at Capitol Metro, the transit system in Austin, Texas, before joining RTC. Her background was in government positions, but she quickly recognized the conservative nature of the Washoe County community and the businesslike philosophy of her Commission. This made her more comfortable with taking risks and looking for creative and effective ways to earn more revenue for the agency. Ms. Kupersmith expressed surprise when advised that her transit agency was regarded as particularly creative. Compared to other areas she had worked in, she found managing transit in Washoe County to be "screamingly easy". She noted that the Commissioners' status as elected officials created significant accountability for them to their respective municipal councils. It was issues dealing with roads that could cause controversy for the commissioners. Consequently, they paid less attention to transit issues. The Commission and community were so enamored of efficiency that she felt she had great latitude to focus on such matters rather than be concerned with the more complex social issues that often surround transit management.

However, according to the managers at RTC, Ms. Kupersmith was not giving herself enough credit. Without exception, RTC managers believed that their director was the basis of their agency's energy. They found her to be demanding of high standards, challenging, and open to change. They credited her for giving clear direction and a relatively wide berth in accomplishing objectives. The RTC's previous director was well respected in the agency and the community, and he established the legacy for excellence within the agency. However, most staff members regarded his style as more top-down and autocratic. He was an engineer whose primary interest was in highway issues. Ms. Kupersmith made no changes to the fundamental structure of the organization, but her trademark was to force interaction among agency managers and involve as many people as possible in the process of decision-making. In doing so, she unlocked a flood of energy that resulted in numerous ideas for generating new revenues and reducing costs. These ideas tended to be developed through a process of collaboration, versus a game of oneupsmanship among managers. 
"I would rather try to persuade a man to go along, because once I have persuaded him, he will stick. If I scare him, he will stay just as long as he is scared, and then he is gone." Dwight Eisenhower

Ms. Kupersmith was a great believer in the power of communications and the importance of building relationships, both internally within the organization and externally with the media, elected officials, and the business community. It has been said that some public program managers make the mistake of regarding the act of lobbying as a military air strike whereby they fly into Washington, make their case for funding, then fly out and think that their mission was accomplished. In fact, lobbying is more like a grind-it-out ground war that requires frequent visits to those you are trying to persuade. Ms. Kupersmith understood this and met with elected officials at all levels of government on a frequent basis to ensure that she understood their needs while also making them familiar with the needs of the RTC. Knowing that they were being kept informed, the elected officials felt that they could trust RTC. This allowed RTC to be aggressive and successful in pursuing discretionary grants from the state and federal governments. This emphasis on frequent communications also allowed the development of positive relationships with the media and the business community. In short, RTC was not a bureaucratic group of strangers to other elements of the community. They were real people who wanted to work with the community in every way possible to provide an efficient service as part of their responsibility to the taxpayer. Ms. Kupersmith noted that "Nature abhors a vacuum", meaning that she felt part of her agency's responsibility was to identify the surface transportation projects that the RTC could do that no one else was doing.

Ms. Kupersmith was a great believer in participatory management and teamwork. Staff members reported that they felt much freer to talk with everyone because they were more familiar with each other's issues. Her greatest emphasis was on the importance of communication. The techniques she put into place are described in the following sections of the report.

\section{Personnel and Personal Matters}

As part of the emphasis on efficiency, Citifare contracted for all of its transit and paratransit operations with private management firms. ATE was responsible for the fixed route bus service, while ATC was responsible for the paratransit services provided through the RTC. This approach was consistent with the philosophy of limited government that was prevalent in the region. They felt it was more cost effective as well.

To help improve communications and teamwork within the agency, Ms. Kupersmith hired a local counselor to administer the Meyers-Briggs personality 
test among the agency's directors. This test helps to identify the type of personality of each individual, and when done in a group setting, everyone participating gets to see how different people react to the same circumstances differently based on their strengths, interests, and personalities. It helps to demonstrate that one personality type isn't necessarily better than another. However, its important that people that work together have an appreciation of the natural differences that do exist among people, and to understand that this doesn't make any of the team members any better or worse than the other. It reinforces the point that if someone else seems a bit different to you, you should realize that you also seem different to him or her. It helps people communicate more effectively with each other because they have a better understanding of the person they are working with. This exercise helped to break down barriers and build trust among the directors, which ultimately led to a greater sharing of ideas. Once information is shared, it generates additional discussion and new ideas can be developed more easily.

\section{"I already know how we do things.}

I want to know how other people from other backgrounds approach issues." Thomas Taelour, Chief Financial Officer

When the RTC hired new employees to join their permanent staff, one person from each department of the agency participated as part of the selection team. They believed that this practice kept all sections more aware of the needs of other sections, and it created more agency-wide buy-in for the selection of each new employee. It also reinforced the message to the applicant that the agency they were applying to work for believed in teamwork and cross-fertilization of ideas.

Many of the managers liked to hire people from outside the state and outside the transportation industry. As Finance Director Tom Talour said, "I already know how we do things here; I want to know how other people from other backgrounds approach issues." The RTC was looking for a combination of technical skill and leadership aptitude in their applicants. Each applicant also needed to demonstrate an aptitude for cooperation and a willingness to act as a supportive teammate of others. This blend of leadership qualities and cooperation was evident when talking with each program director. They were all highly motivated to succeed individually, but they were excited to make progress as a team. Based on having these qualities, and being well informed of agency issues, it was commonly believed that any of the seven department directors could be the Director of the RTC.

The RTC was very supportive of professional development for its staff. Even though the agency had to make budget and service reductions due to the shortfall of tax revenues, there was never any consideration given to eliminating funds for staff to be members of professional societies or to attend conferences. Ms. Kupersmith was very active in encouraging her staff to take 
site visits to the transit agencies that had achieved success in areas that Citifare wanted to learn more about. For instance, managers were sent to the Sacramento Regional Transit Authority to learn about CNG fueling systems, to the Ann Arbor Transportation Authority to see how that agency was implementing Advanced Public Transportation System elements, and to Spokane to gain information on the development of a new downtown terminal.

RTC staff were also members of regional and national committees including APTA and the Transportation Research Board. The simple but effective strategy was that the more their staff interacted with other industry participants, the more likely they would be to find some new ideas that might have application in Washoe County.

The RTC provided tuition reimbursement for its staff to pursue college degrees. The agency also established a revolving fund to purchase computers on behalf of those staff members who did not own one at home. Staff members were encouraged to purchase a computer for their own home use through the revolving fund. Employees were allowed to pay for the computer over three years with no interest costs. The agency felt this was one way to encourage their staff to become more computer literate, and to increase their efficiency and productivity on the job. Sixty-five members of RTC's staff took advantage of this program. Another technique used at the RTC to encourage creativity in developing new efficiencies was the establishment of an Employee Suggestion Program that provided cash awards of up to 10 percent of the value of the savings to the agency.

As was noted earlier, the RTC contracts out its transit operations to the ATE transit management company. ATE is in turn responsible for hiring all of the bus operators for Citifare. The manager of bus operations, Michael Steele, is a firm believer in the utilization of employee selection screening tests that help the agency hire applicants who are the most likely to have good attendance, safe driving habits, and good passenger relations skills. The remarkable aspect of RTC's practice is that it uses employee selection screening tests from four different sources. Mr. Steele believes that each test focuses on different aspects of the candidate, and they serve as filters that allow RTC to select the candidates with the greatest chance for success as a bus operator. This practice has helped Citifare enjoy an absenteeism rate among bus operators that is approximately one-half the national average.

Citifare is also one of the few transit agencies in the country that utilizes a "Group Supervisor" program that recognizes the need to ensure that each bus operator has a personal connection with someone in the agency. In most transit agencies, bus operators might never speak with a supervisor unless it is for disciplinary reasons, or to be recognized for outstanding work. They are on the road for their entire work shift and do not enjoy the normal relationship that those who work in an office setting have with a supervisor. This can lead 
to an atmosphere where the operators feel no sense of loyalty to the agency, because the agency seems not to care about the operators. The Group Supervisor program assigns each operations supervisor approximately 25 operators that he or she meets with on a regular basis to ensure that each operator maintains a point of contact with the agency. This greater personalization of the workplace helps to convey that the management of the agency cares about the well being of its bus operators. The operators, in turn, are more likely to offer their suggestions on how the agency can improve its service and its efficiency.

\section{Organizational Structure, Practices, and Philosophies}

As noted earlier, Ms. Kupersmith did not modify the basic organization she inherited when joining the agency in 1993. Her primary organizational change was to encourage and force greater communications and interaction among her staff and with the community. One of the most significant mechanisms she established to accomplish these objectives was the creation of the Service Review Committee. This committee was comprised of 12 people representing virtually every department within the agency, including bus operations, maintenance, planning, scheduling, customer services, human resources, marketing, administration, and operations supervisors and bus operators as well. This group met every two weeks to go over the performance of each route and the system as a whole to identify what changes could be made to improve performance and efficiency. The old process of having just a handful of planners and schedulers develop whatever changes they felt were necessary was replaced by a more comprehensive product development process that reflected the points of view of every element of the agency. Ms. Kupersmith was not a member of the Service Review Committee. She realized that the presence of the Director could stultify the interaction of the group. However, she did review every recommendation for change after the committee developed them, and challenged them when necessary. The Service Review Committee meetings made all departments of the agency more familiar with each other and more comfortable in sharing ideas to make the transit system more productive and efficient.

In similar fashion, Ms. Kupersmith instituted management team meetings among department directors that lasted up to four hours each week. All items that were to go forward to the Commission were reviewed by all members of the management team and required unanimous consent prior to being submitted to the Commission. This practice helped build comradery and trust among department directors and allowed for a greater flow of ideas among staff in identifying ways to make the agency more efficient. 


\section{"Leadership and learning are indispensable to each other."}

John F. Kennedy

Each year, as part of the budget preparation process, the management team held a twoday retreat to ask the fundamental questions of where the agency wanted to go, and how they were going to get there. Nothing was held sacred. Each department was then charged to come up with their own program, but the management team as a whole, not just the Director, reviewed each program. Again, this process permitted more comprehensive review of proposals and spurred more sharing of ideas for new ways of improving productivity in the agency.

In 1994, when the agency had to cut back costs due to lower-than-expected sales tax revenues, the RTC established a Blue Ribbon Committee of 30 representatives of

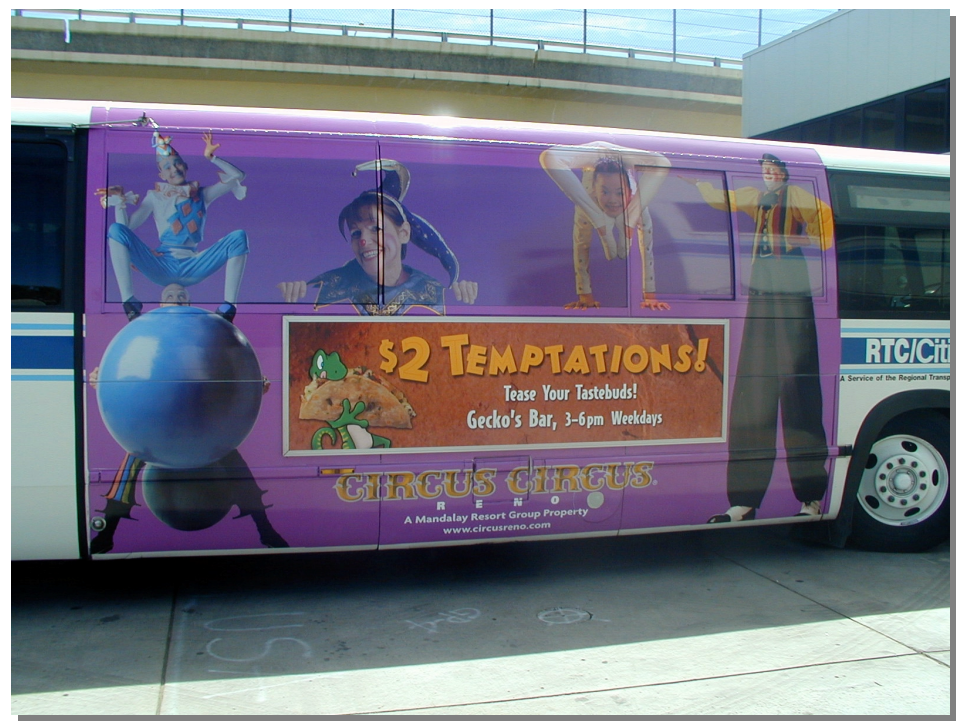

Focusing on selling advertising space to local businesses resulted in tripling revenues and more support from local businesses who now had a stake in RTC's success. both the public and the private sector in Washoe County to help identify ways to get through their budgetary challenge. This process helped the agency identify some additional ways to cut costs. It also helped develop a closer relationship between the agency and the members of the Blue Ribbon Committee. Committee members came to realize that the RTC already ran quite a tight ship. They became advocates for new revenues and grants for the RTC, and they also became more aware of how they could partner with Citifare to their mutual benefit in ways that helped RTC expand transit service and increase ridership and revenue.

The RTC utilized the services of the private sector extensively in their transit services. As mentioned earlier, Citifare contracted with ATE Transit Management Services to manage their bus operations and maintenance functions. The agency saw a great benefit in taking advantage of the knowledge and depth of talent available through a private transit management firm. Both the bus maintenance and operations directors, who were employees of ATE, participated in regular teleconferences with their peers throughout the nation to share information on successes and failures. This practice helped to make their company as competitive as possible when proposing for new transit management contracts around 
the country. It also provided immediate benefits to the transit agencies that they were serving. ATE was a subsidiary of Ryder Systems, a company that had accounts in 226 locations throughout the country. This company conducted a great deal of its own research on such matters as the cost-effectiveness of synthetic oils, heavy-duty light bulbs, new filters, etc. The results of this research helped reduce costs at each local transit agency they contracted with.

Another example of utilizing the private sector to make the transit system more efficient was the hiring of consultants with special expertise in conducting a "comprehensive operations analysis". This analysis helped identify how transit service hours could be reallocated and rationalized to result in greater ridership at no additional cost. The consultant's tasks were made somewhat easier due to the RTC's diligent collection of ridership data by route segment, by trip, and by time of day. The RTC staff realized that marketing their service began first with understanding their market, and they put appropriate resources into ridership surveys. 


\section{SunLine Transit Agency}

"I've done the math.

Less than $10 \%$ of our residents

use our bus service.

How can I make our agency

relevant to the other 90\%?"

Richared Cromwell III,

General Manager and CEO

\section{Environment and Conditions}

SunLine Transit is a Joint Powers Authority that was created in 1977 by the County of Riverside and various cities to provide public transit services within the Coachella Valley. The Coachella Valley is located in the eastern portion of Riverside County, California, about 120 miles east of Los Angeles. The population in SunLine's service area is approximately 270,000 . The area retains a relatively small town feel where residents get along quite well and tend to know each other. Perhaps the bestknown city in the valley is Palm Springs, a popular resort area and home to entertainment industry giants. The Coachella Valley is characterized by dry desert climate. The author of this report visited SunLine in the month of July, when temperatures reached 122 degrees. He was told, however, that it was a good thing he wasn't there in August, when in gets really hot!
Household income varies drastically throughout the valley, ranging from cities such as Palm Desert and Indian Wells with incomes in the upper two percent of all municipalities in the state, to cities such as Desert Hot Springs and Coachella with incomes in the lower ten percent in the state. None of the cities are large enough to attempt to provide regional services such as public transit. However, they are located considerably east of the primary centers of population in the incredibly long Riverside County. It is a common belief among people in the Coachella Valley that the area is a weak stepchild of the county when it comes to receiving regional services.

Based on their economy being strongly dependent on tourism and agriculture, and their own desire for a high quality of life, the people of the Coachella Valley are also concerned about the environment, particularly their air quality. There was a great deal of nervousness about the approaching smog from the Los Angeles air shed just to the west. In addition, the mountains in the area and the dust and sand from the desert also contribute to problems with air quality.

The Coachella Valley has traditionally been a very conservative area politically. There is a strong expectation that government services will be efficient. New taxes are not on the horizon for transit. Transportation improvements and services are funded through a one-quarter cent sales tax that is divided between roads and transit. The portion of the sales tax revenues dedicated 
to roads is pledged to bonds that have been issued, so there is no real chance for those dollars to be reallocated to transit. In addition, SunLine Transit suffered the same losses in federal transit operating support as other transit agencies throughout the country during the mid-1990s. The agency had to try to make up over $\$ 400,000$ caused by the loss of federal operating experience. In addition to these factors, SunLine Transit operated one of the oldest diesel bus fleets in the nation through the late 1980s and into the early 1990s. The buses they used had been acquired from Orange County after they had accumulated 500,000 miles, and experienced extremely high failure rates. On one day in 1990, 27 of the 37 buses needed for peak service broke down while in service.

All nine cities in the Valley as well as the County are represented on SunLine's Board of Directors. An interesting aspect of the Board is that there are members who have business experience, are visionary, and are fairly wealthy. According to many SunLine staff members, these characteristics contribute to a pioneering spirit and a willingness to experiment. Business people understand that risk and reward are inseparable. They are not afraid to take a chance and take advantage of opportunities. Wealthy people also have more opportunities to do new and unusual things. Finally, there are many that believe that "the desert" is an environment that puts one to the test, and is therefore an area that is more open to things that are different and innovative.
What was lacking was a transit leader who could put the following puzzle pieces together. The Coachella Valley was an area that:

- believed in low taxes and government efficiency;

- had a gap between the services that were provided by the cities and the county;

- had a bus fleet in dire need of replacement

- had strong concerns about the environment and air quality;

- had a can-do attitude and a sense of selfreliance;

- had leaders who understood risk and were willing to experiment

In 1991, the SunLine Board of Directors promoted their Assistant General Manager for Marketing to the position of General Manager. The puzzle was about to be put together.

\section{Leadership}

Richard Cromwell III brought a relatively unique blend of backgrounds to the position of General Manager. Prior to joining SunLine Transit, he had been a prominent businessman and elected official. He was a former (and respected) city council member and chairman of the School Board. He had also been the general manager of Walker Scott, a prominent department store in California. This blended background of politics and retail was clearly a very appropriate mix for this transit manager. 
His political experience allowed him to understand the mindset of elected officials and communicate very effectively with them. He understood public policy issues in the region, and had an innate sense of responsiveness to the public as a former elected official and public servant. It should also be noted that SunLine's Board contributed significantly to the leadership necessary to make the agency a hotbed of creativity. Palm Springs was already a leader in neighborhood electric vehicles, while Palm Desert was experimenting with four fuel cell vehicles. Many of the Board members were strong advocates of environmental issues and Mr. Cromwell was given clear direction to pursue air quality goals. In addition, Board member and mayor of Palm Desert Dick Kelly won APTA's 1998 State and Local Distinguished Service Award presented to the state or local official that makes the most outstanding contributions to public transit through policy or legislative initiatives and/or leadership. While many board members already wanted to push the envelope, they found someone in Dick Cromwell who could implement some of their concepts.

Based on his experience as a retail department store manager, Mr. Cromwell brought a strong sense of customer service and orientation, something that much of the rest of the transit industry has seemed to only recently discover is important. In fact, the union shop steward at SunLine noted that every represented employee in the agency knew that the customer came first. He stated that the union could probably save almost any member's job, except for someone that had committed a serious customer service infraction. There was simply no tolerance at SunLine, under Richard Cromwell, for less than friendly, professional service, and that philosophy was shared by the union.

Mr. Cromwell stated a simple truth more clearly than this author had ever heard it expressed by a transit manager before. $\mathrm{He}$ stated that SunLine's farebox revenue comprises only $20 \%$ of the operating

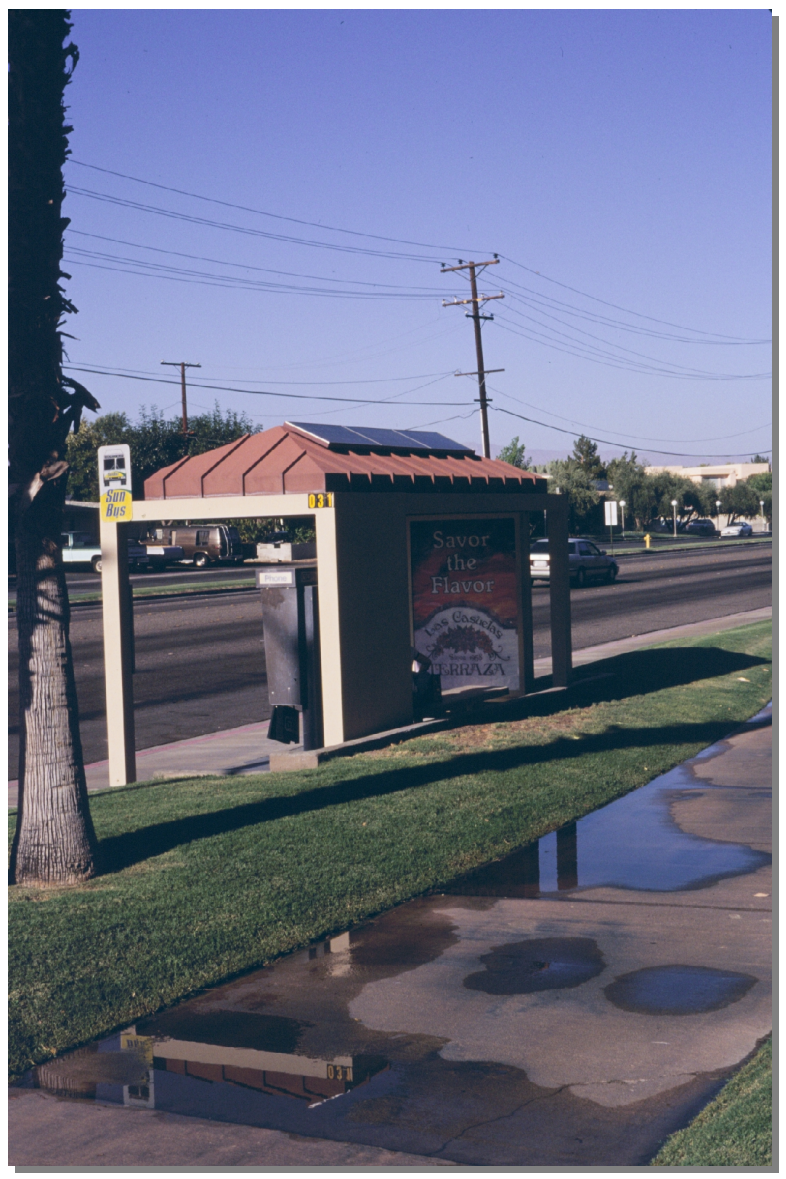

SunLine's bus shelters remain lit at night from power received through roof-mounted solar panels. 
expense of the agency, and that less than 10 percent of the residents of Coachella Valley actually use transit service. In short, he fully understood that the vast majority of the residents of the Valley pay for the transit system, but don't use it. He asked, "If I expect support for the agency from the community, what else can we give the public?" He stated one other fact that influenced his approach to managing the agency: "Eighty percent of all federal transit funds go to 20 percent of the transit agencies in the country. For us, Washington isn't the cure. However, we do need to find ways we can differentiate ourselves from the rest of the 80 percent."

Mr. Cromwell stated, "One role of leadership is to recognize who the boss is and where the money comes from." In this case he regarded the passengers and the local taxpayers as the primary bosses, and directed his agency's efforts to please these players. In fact, the organization charts for SunLine Transit always places "The General Public" and/or "The Customer" at the top of the chart, above the Board of Directors and General Manager.

Mr. Cromwell knew that SunLine could help itself financially and endear itself to the local residents if it could develop new services that were needed in the Valley. He knew there was a gap in services between what the cities were capable of doing and what the County was willing to do. He realized that SunLine Transit was an established agency that could deliver services that neither the cities nor County were willing to undertake. He also knew that clean air was an issue, and that the area would like to broaden its economic base if at all possible. He seized upon alternative fuels as a way of not only addressing the community's concerns about air quality, but as a way of earning revenue and assisting the economy of the Valley in a variety of ways that will be described in the Organizational Structure and Practices section below.

\section{"As soon as you become complicated, you become ineffective." Konrad Adenauer}

Mr. Cromwell was described by all of his agency managers as a visionary and champion. His Human Resources manager noted that working with him was an exercise in non-stop mental gymnastics. He was not a trained scientist or engineer, but he was intrigued by technology. Staff noted that he read all the time, either technical journals (which were prominently displayed throughout the administration offices) or information from the Internet. $\mathrm{He}$ was acknowledged to be very creative and someone who thought in big terms, but was practical enough to attempt things a piece at a time. His Deputy General Manager, Tracy Daly, also stated that he had a pure heart. He was not a publicity hound looking for self-aggrandizement. He really did want to advance the agency and serve the community in ways that were complimentary to agency and community success. 
His staff described Mr. Cromwell as the "interpreter of the vision". He saw his role as a leader in developing the agency's vision, and helping his staff develop the scope for implementing it. However, he did not want to micromanage. His standard charge to his managers was, "It's your department - run it." But that freedom came after carefully developing a strategic plan for the agency that provided the foundation for all managers' actions. Other elements of his leadership style are described in the Organizational Practices section.

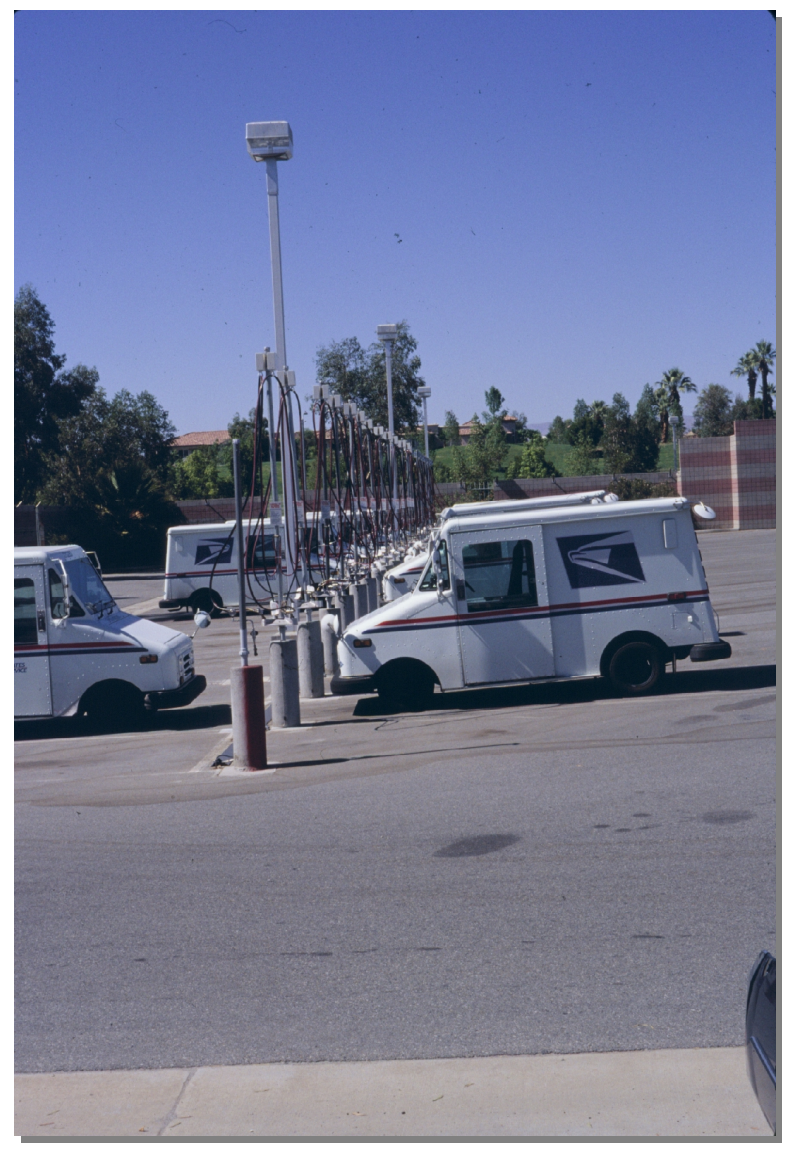

Through a public/private joint venture, SunLine provides CNG fueling services to other fleets of vehicles in the region, thereby improving air quality and generating revenues.
One other prominent feature of his leadership was his recognition of the crucial importance of communication. He believed in "bombarding" his Board with information. "They must be educated, since they ultimately make the decisions for the agency," he noted. Mr. Cromwell not only developed thorough briefing papers for the Board before every meeting; he also produced audiotapes of white papers and the minutes of prior meetings for Board members who might not have time to read those documents prior to meetings. Mr. Cromwell understood that solid communication builds trust between the board and the staff, and that allows the staff to experiment even more. Mr. Cromwell and the Board worked together to develop an umbrella of political will that defined a level of risk that the Board accepted as long as they were kept informed.

\section{Personnel and Personal Matters}

Mr. Cromwell believed in surrounding himself with good people from a variety of backgrounds. His department managers were not selected in cookie cutter fashion, and many did not have backgrounds in transit prior to joining the agency. For instance, his Deputy General Manager was a grant writer for a private non-profit foundation prior to joining SunLine. The director of Human Resources had a background in the hospitality industry. The director of his special services division came from the research and development branch of the Air Force. 
The entire management team would review the background of candidates for key positions and participate in the interviewing process. The union is also represented on such interview teams. Very often, and depending on the position, the agency would hire "the person" more than the candidate's skill. They were interested in hiring people of good character who were independent thinkers. Mr. Cromwell noted that being the General Manager at SunLine was a bit like "herding cats", but he valued the staff members' abilities to think out of the box. However, the team interviews helped ensure that the people that were hired were fundamentally compatible with the team already there.

The Deputy General Manager, who was a female, made one other interesting observation regarding organizational techniques. She believed that in such an innovative agency, it was very helpful to have a "buffer" between the various directors and the General Manager. She believed that many men (and virtually all of the directors were men) are reluctant to admit mistakes or failures to a male General Manager, no matter how deeply they respected him. She felt they could more easily confide in a woman, and they found ways to resolve issues without tempting the General Manager to "fix it".
It was also noted by some of the managers that the small size of the agency contributed to their ability to work together. The barriers associated with most large bureaucracies don't exist at SunLine. All of the directors feel empowered to take risks and solve problems in new ways.

SunLine exercised "team" evaluations of the program directors. This process helped to validate every manager's role at the agency, and was credited for helping to build teamwork and harmony. Maintenance Manager Earl George mentioned one small example of teamwork that existed at SunLine. He noted that operations and maintenance managers at most transit agencies often quarrel over the problems that buses have and who is responsible for them. At SunLine, when a bus comes in, both the operations and maintenance directors-in-charge take two minutes together and inspect the bus and talk with

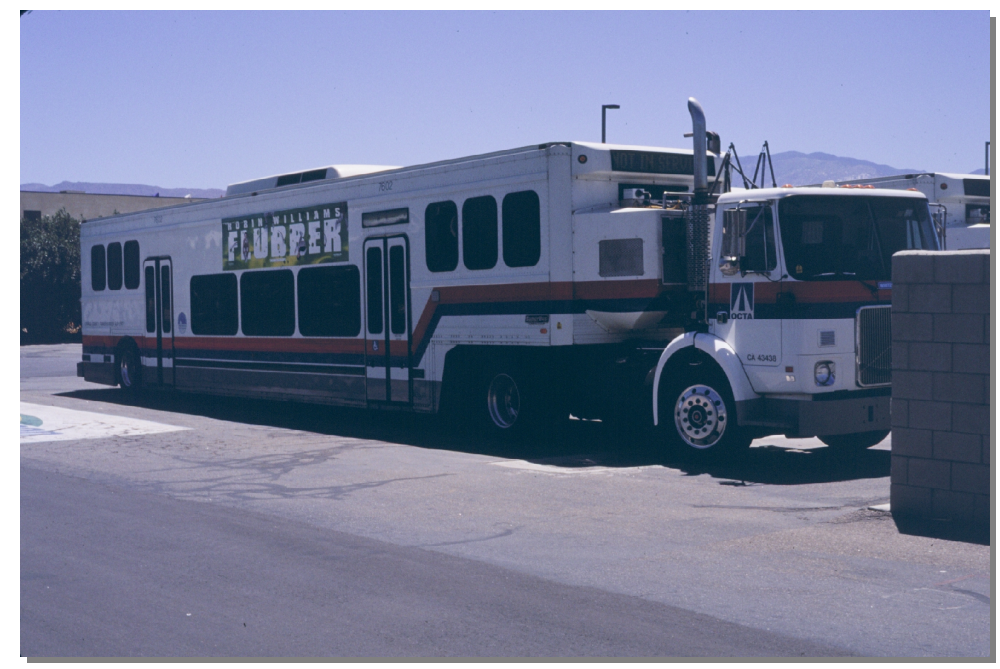

This big rig is actually an express transit vehicle that provides living room comforts to passengers connecting with regional rail services. 
the operator about how it ran. This practice helps avoid the finger pointing that sometimes occurs when a bus is found to have a problem the next day.

Mr. Cromwell also believed in staying in touch with all employees of the agency through annual surveys. This allowed the agency to get feedback from the employees on whether or not they were doing what they, as an agency, said they were going to do, and how well they were doing it. It was also a valuable tool to collect ideas from their employees, such as the bus operators' desire to wear shorts.

In the Maintenance Department, the manager didn't mind hiring people "off the streets." They looked for people with acceptable reading skills and computer literacy skills, and from there the agency was willing to train them. Given their pioneer status in the field of implementing Compressed Natural Gas bus service, it might have been to the agency's advantage to have people who entered their workforce unencumbered with standard diesel maintenance background. SunLine worked with the College of the Desert to develop a curriculum for the maintenance of $\mathrm{CNG}$ vehicles and facilities. This same curriculum is now used at nine different colleges in the country. SunLine's maintenance managers regard in-house training as the key to their success. It helps both supervisors and mechanics to stay upto-date. They do not rely on vendors' representatives for training; they see vendors' roles to be troubleshooting and selling. SunLine now makes a concerted effort, along with the College of the Desert, to attract high school students who don't wish to pursue four-year college degrees. They advise them of the opportunities to get a junior college degree with an emphasis in the maintenance of alternative fueled vehicles. This will help to provide a new stream of well-qualified technicians as they continue to operate $\mathrm{CNG}$ buses, and move toward fuel cell buses in the future.

Training on CNG was not limited to the maintenance staff. The fundamentals of CNG were required learning for everyone at the agency. For instance, they knew that passengers and bus operators would be concerned about the safety of this new fuel. The operators, through training, became familiar with CNG technology and were assured of the fuel's safety. As the first point of contact with SunLine's customers, the operators could also help assure the passengers of the fuel's safety as well. This was consistent with the agency's commitment to communication and customer service.

Mr. Cromwell "walked the walk" when he stated that SunLine's most valuable asset was its personnel. He worked hard at building trust between managers and the union employees. The union was allowed to evaluate new supervisors. While some might question this practice, it was a sign of how much respect and common values existed between the managers and the field staff. There had only been two disciplinary cases that had gone to arbitration in the past 
ten years. Neither the union nor management used attorneys when negotiating labor agreements. Negotiations for the most recent labor agreement took only three days.

\section{"I believe SunLine has the employees' interest at heart. As a result, there isn't anything we can't resolve."}

Neil Silver

President, ATU local 1277

SunLine used part-time bus operators, as many transit agencies throughout the country also do. However, their utilization of part time employees was unique and indicative of both the agency's concern for its employees and the agency's entrepreneurial creativeness. The part time operators helped keep the agency's cost of operations down, and provided SunLine with a pool of employees to do work other than operating a bus, which will be described below. The key factor for part time employees was that the work made available on other services provided by SunLine gave them extra income, usually enough to cause them not to seek work at other employers. This helped SunLine maintain a good record of employee retention, thereby reducing the costs of absenteeism and turnover. As Local 1277 President Neil Silver stated, "I believe SunLine has the employees' interests at heart. As a result, there isn't anything we can't resolve."

\section{Organizational Structure, Practices, and Philosophies}

As noted earlier, Richard Cromwell wanted SunLine to be relevant to all the residents of the Coachella Valley, whether they used public transit or not. He asked, "If I expect support for the agency from the community, what else can we give the public?" $\mathrm{He}$ recognized there were many services SunLine could provide if they didn't restrict themselves to focusing only on transit. $\mathrm{He}$ challenged his directors to find ways to make SunLine more valuable to the community. They decided to expand their responsibilities as an agency to take responsibility for other revenue generating services that neither the cities nor the County were providing. The agency determined that this would provide a way to

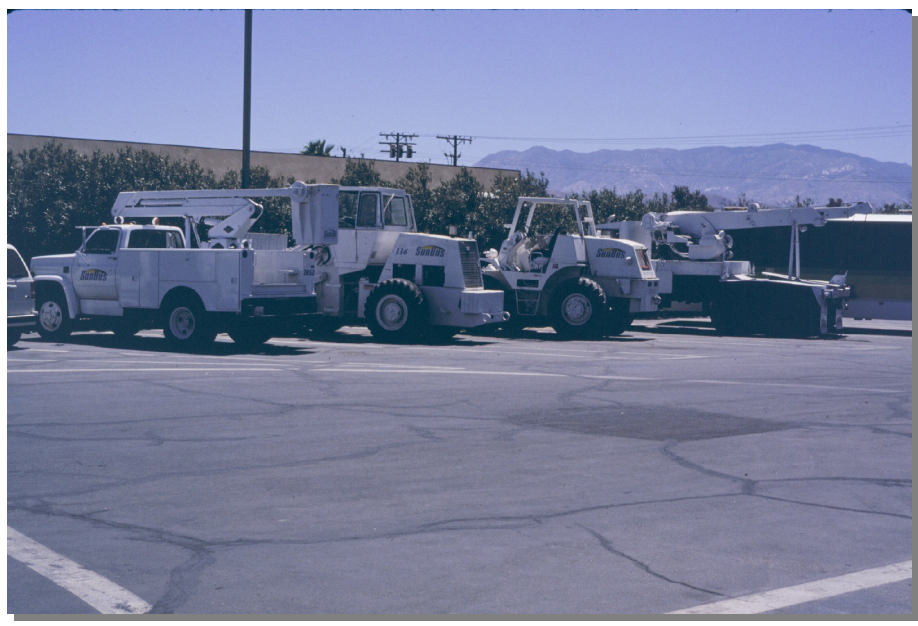

All of SunLine Service Group's vehicles are white and run on compressed natural gas. 
make up for the shortfall in federal operating assistance, allow them to avoid laying off their employees during the tough times, and generate positive and well-earned acclaim from the community.

The key to doing this was establishing the SunLine Services Group as an adjunct to the agency. The agency started by affirming that Compressed Natural Gas was good for

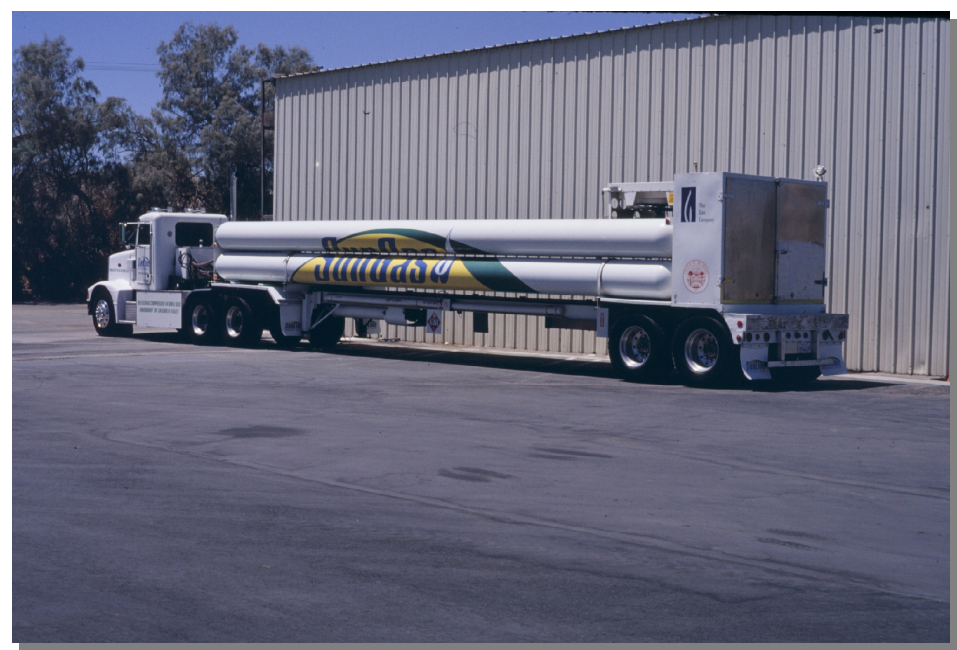

This unique mobile CNG fuel compressor allows SunLine to fuel other vehicle fleets at remote facilities. SunLine, and could also be good for all of Coachella Valley. SunLine was the first transit agency in the country to convert its entire fleet to run on CNG. Maintenance managers at SunLine stayed in close touch with Pierce County Transit in Washington, and the Regional Transit Authority in Sacramento, both of whom were also converting their fleets to CNG using Orion buses. SunLine kept exhaustive records of their maintenance and operating costs and the agency was able to show the community that not only was CNG a cleaner fuel alternative with air quality benefits for the region, but also a more economical fuel to utilize as well. SunLine claims it costs them $\$ .20$ less per mile to operate CNG buses versus diesel buses. They also boast a range of over 30,000 miles between road calls, and they have been able to reduce the size of their parts inventory by more than half. With this information as ammunition, the agency helped persuade other agencies with major fleets in the Valley to convert to $\mathrm{CNG}$ as

well. The members of SunLine's Board were also extremely instrumental in assisting the agency's efforts to provide $\mathrm{CNG}$ and other services to the local cities. All nine cities in the Coachella Valley were represented on the Board through their mayors or council representatives, and these members helped persuade their own city councils to utilize the new services being offered by SunLine. SunLine entered agreements that called for a unique system of fueling all of the Postal Service mail delivery vehicles and garbage trucks that operated in the Valley. A large, mobile CNG fueling vehicle traveled to the fleet storage areas and fueled the mail delivery vehicles and garbage trucks each night. SunLine shared the profits realized from this venture with Pickins Fuel, a private company that was awarded the contract to operate the mobile fueler. 


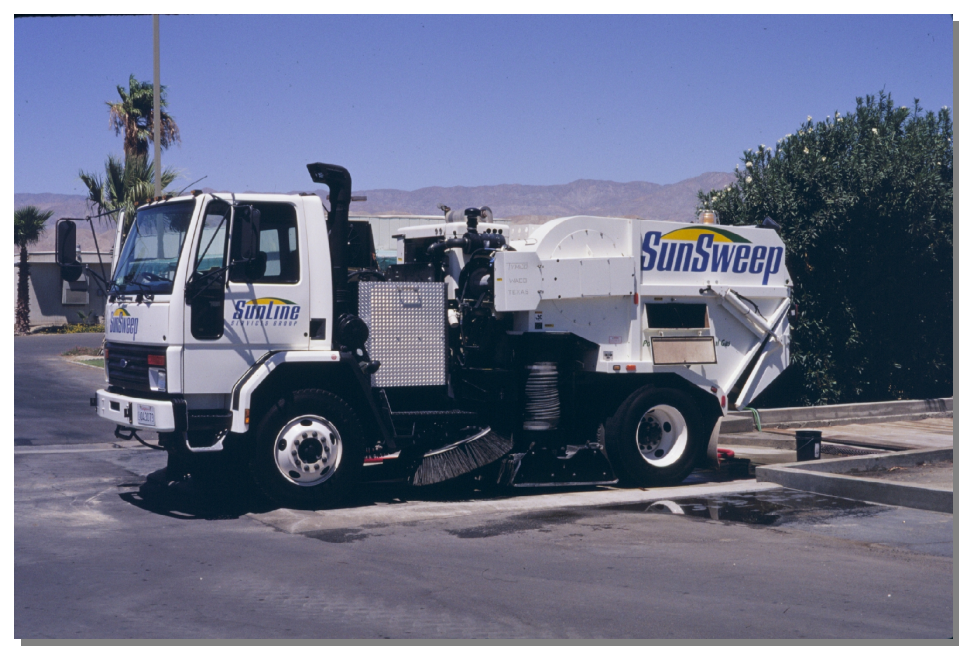

CNG street sweepers are just one example of how SunLine has enhanced its value to the region. agencies such as changing streetlights, traffic signal maintenance, graffiti removal, watering plants at highway intersections, providing emergency lights and generators at major community events, and building levees for flood control districts. In keeping with their commitment to clean air, the agency modified the vehicles used to provide these services to operate on CNG. The services were provided through contracts with cities and other entities in the Coachella Valley that allowed the Although the staff fully understood that SunLine was indeed a public agency that answered to a Board made entirely of elected officials, they didn't think of themselves as a typical government agency. The taste of entrepreneurial opportunity gained through the opportunity to sell $\mathrm{CNG}$ through a partnership with a private company became quite infectious throughout the agency. SunLine staff began to identify other opportunities to provide services in an environmentally friendly way. The agency sold CNG through pumps at their facility to any public or private vehicle that could utilize the dispensers. Key staff members maintained close ties with military bases in the area and looked for opportunities to purchase vehicles not ordinarily seen at most transit agencies. They purchased surplus army vehicles such as forklifts, bucket trucks, cranes, water tankers, mobile generators, and wreckers. This put the agency in a position to offer certain services to cities and other public agency to hire additional personnel that could be used for other activities at SunLine as well. All of the vehicles used for these services were maintained by SunLine mechanics and operated by SunLine parttime bus operators. This arrangement delighted the union, who appreciated the ability to maintain and grow the number of dues paying members by virtue of these new opportunities. This helped SunLine avoid the turnover that often plagues transit systems that use part-time operators.

\section{"We're the silicon Valley of CNG. We're a Beta test site for anything that moves." George Earl, Maintenance Manager}

SunLine's Services Group also applied for and received grants from the regional air quality district to purchase street sweeper vehicles. Of course, these too would be 
operated on CNG. The SunLine Services Group proved to be an organizational branch that allowed the agency to earn new revenues, support economic development and research in the Valley, fill gaps in public services, and gain new friends. All of SunLine's vehicles were painted pure white and included no advertising, except for SunLine's name and a message that the vehicle used compressed natural gas. The pure white paint helped reflect the sun and reduce heat build-up in the vehicles. However, this was also a very conscious strategy on the part of SunLine's staff to promote their agency's image as the clean and environmentally sensitive service provider in the Valley.

SunLine staff regard themselves as a "Beta test site for anything that moves." They work closely with Detroit Diesel, Cummins, John Deere and other manufacturers who look for places to test the equipment that the private companies' research and development staffs develop. In one example, SunLine entered into an agreement with a company that wanted to test a $\mathrm{CNG}$ generator that could provide power to employment sites in place of normal electric power. This piece of equipment would normally sell for $\$ 100,000$, but was purchased for less than $\$ 10,000$ by SunLine after the agency served as its test site.

The SunLine staff thrives on converting vehicles to CNG. This dedication to innovation keeps the environment challenging and interesting to mechanics and managers. They enjoy coming into work each day; they are never sure what they will be seeing or working on. The maintenance personnel are always learning and teaching. It is not unusual for SunLine maintenance personnel to be talking with representatives from foreign countries who came to SunLine to learn from the agency's experience with alternative fuels.

SunLine's managers maintained strong contact with associations that provide links to community goals. They were members of the California Economic Development Association, and their Deputy Director Tracy Daly served as Chair of the Clean Cities Coalition. SunLine wanted to be regarded as a regional resource, not a tax burden. They wanted to be known as problem solvers. Staff members had a high sense of mission. Their dedication to $\mathrm{CNG}$ was not only to help achieve area clean air objectives, but to spur research and development in alternative fuels that might result in economic opportunities in the Valley as well. Maintenance Director George Earl described Coachella Valley as "The Silicon Valley of CNG", and SunLine was at the forefront. The research that is being done at their site is bringing federal and state money into the community.

It is clear that SunLine's managers rely on sound strategic planning to guide their actions. Each year, all directors go off-site to discuss everything about the agency. They utilize a facilitator, but the directors as a group write their own action plan for the agency. This management team also meets for two hours each week to review progress 
against jointly developed action plans. In 1996, the agency developed a five-year strategic plan through an effort that included the participation of the Board, executive staff, front line employees, the Amalgamated Transit Union, and other local partners such as the College of the Desert, Southern California Gas Company, and local cities among others. The Mission Statement developed through this process reads as follows:

"To provide and expand innovative public transit services for the Coachella Valley - with a commitment to excellence and environmental leadership."

The Strategic Goals were identified as follows:

- $\quad$ Link the Coachella Valley Through Seamless Transit Service

- Enhance our environment through leadership and technology

- Empower a strategic thinking ethic in the team

- Pursue partners who complement our strengths

It took many weeks to develop the plan, but it is clear that the mission and strategic goals reflect the mindset of the agency and all the personnel within it. Directors are evaluated each year based on how well they have advanced these goals, both on a qualitative and quantitative basis. A few of the agency's "core values" as identified in the strategic plan are worth noting as well:

- We value our employees

- We are entrepreneurial

- We seek effective partnerships

- We work together as a team

- We are problem solvers

It is interesting to note that every one of the 11 core values begins with the word "We". Managers at SunLine say they live these values every day.

The agency's need to connect with the community is further reflected in the practice of requiring their managers and supervisors to be involved with community groups, whether they be governmental bodies, schools, senior centers, or other community-based agencies. The agency understands the importance of knowing what is important in the community, and expects their employees to be active members of the Coachella Valley community as well as committed members of a vibrant and multifaceted transit agency.

\section{Notable Results}

By instituting the creative ways of earning new revenues, SunLine was able to avoid laying off all but a small handful of employees, and even those were recalled within 60 days. The agency more than made 
up the $\$ 400,000$ shortfall in federal operating assistance. In fact, the agency was able to provide small, but symbolically meaningful gain-sharing checks to all of the employees in 1999 that were well received after a few years of wage freezes (including managers). The staff took pride in their frugality. To a person, they believed that whatever money might be available should be spent on the taxpayers, not on themselves. The gain sharing "bonus" was only available due to agency-wide accomplishments.

For most employees at SunLine, everyday is different. It is exhilarating. It is fun. One minor drawback mentioned by at least one manager was that the staff gets so involved in non-traditional transit work that they sometimes have to ask themselves, "Wait a minute - why are we here?" The one risk some managers feel is a fear that they won't be able to "top themselves." However, this has not appeared to be a problem to date. In fact, the innovations just keep coming. SunLine's Board now expects outside of the box thinking from its staff. The agency recently was awarded a $\$ 3,000,000$ grant sponsored by the Department of Energy, the Southcoast Air Quality District, and the City of Palm Desert to build a hydrogen producing plant at the SunLine Facility. The hydrogen plant will produce the fuel necessary to run vehicles powered by fuel cells. The transit agency wants to produce zero emissions with its vehicles, if possible. As they were with CNG, SunLine envisions being the first transit agency to operate a totally hydrogen-powered bus fleet. And once again, they will show the way for the rest of the nation.

SunLine now provides technical tours of its facilities on Friday mornings. Visitors may be local, but many are from out of state or international. Staff estimates these visitors have accounted for over 5,000 room nights in local hotels, as well as thousands of meals and other tourist expenditures. It has been just one more way SunLine has added value to their community. 


\section{Lynx-The Central Florida Regional Transportation Authority}

\section{"I know it sounds a bit bizarre, but in Camelot. . . \\ That's how conditions are." \\ Alan Jay Lerner}

\section{Environment and Conditions}

Lynx is the name of the transit system that serves Orange, Seminole, and Osceola counties in the Greater Orlando, Florida area. This transit agency has not always been called "Lynx". From the 1970s through the early 1990s it was alternately called OSOTA (Orange Seminole Osceola Transit Authority) and TCT (Tri-County Transit). Up until the early 1990s, TCT was a small transit system ( 80 buses during peak service) managed by the ATE transit management firm.

During these years, while TCT remained a relatively quiet agency, the area in which they operated experienced a boom to rival the fastest growing areas in the nation, if not the world. As everyone now knows, the Disney Corporation was allowed to develop what has become perhaps the world's most famous theme park, Disney World. In short order, other major tourist attractions including Universal Studios and Sea World also moved to the greater Orlando area, giving even greater impetus to the region's growth. The National Basketball Association awarded a professional sports franchise, the Orlando Magic, to the region. The population of the area grew to over $1,000,000$ by the late 1980 s.

All of this phenomenal development required the region to seriously address its transportation infrastructure. A major international airport with 120 gates was built to accommodate the flood of national and international tourists visiting the area. Three new expressway authorities were established in the tri-county region to help accommodate the demands on the highway network caused by the visitors to the area and its exploding full-time population. In stark contrast, Tri-County Transit remained a sleepy organization that was invisible to most people in the community. In fact, in surveys taken in the early 1990's, over 85 percent of residents polled could not name the regional transit system. Some thought TCT was an illegal drug! In accordance with the direction given to them by the Board of Directors at the time, ATE operated a traditional fixed-route bus system, offering service that could only be usable to those with few travel choices. Ironically, the region had substantially more private charter buses than it had public transit buses.

Although the area's economy was booming, primarily with service-related industries, the Greater Orlando Chamber of Commerce was trying to diversify its mix of employers and was attempting to attract a prominent 
manufacturing company to relocate to the area. The company decided against relocating to the region based on the fact that the area's public transit system was inadequate to meet the needs of their employees. It was becoming clearer to some that public transit was important to the business community, whether it was to attract new businesses, or to help provide mobility to the tens of thousands of employees who worked in a relatively low wage service-dominated economy and the thousands of tourists that were in the region each day. In the midst of all the world-class development driven by some of the creative giants of the world, Tri-County Transit simply wasn't keeping pace. It was a small transit agency without a dedicated source of funding that relied on annual requests to participating governments for its operating revenue.

However, in the early 1990's, the planets started to align in transit's favor in the greater Orlando area. There were local leaders who recognized that transit could be an important element in the community, even in an area absolutely dominated by the automobile. These leaders saw the possible benefits that public transit could bring to the region.

\section{Leadership}

Two prominent local leaders made it a high priority to become members of the Board of Tri-County Transit. Orlando City Commissioner Frankie Hellinger campaigned for her position as a commissioner on the basis of supporting public transit, something virtually unheard of in the region. She was very concerned about preserving neighborhoods and enhancing the development of downtown Orlando, given the prominent move of most development toward the theme park complexes. Although she herself was an elected official, she believed that transit policy had to be developed by more than only politicians. She wanted to modify the Board to get greater input from other elements of the community. However, she was a vital link to the political community in the region and state.

Perhaps the most prominent leader to influence the change in transit in the region was Jacob Stuart, president of the Greater Orlando Chamber of Commerce. Mr. Stuart understood first hand the importance of transit to business, particularly after the major corporation noted earlier decided against relocating to Orlando. Mr. Stuart was also a world traveler who saw for himself that great cities have great public transit systems. Fortunately for transit in the greater Orlando area, Mr. Stuart was blessed with great vision for the region, and an ability to see the big picture. Given his own business experience and his links to the entire business community in the region, he approached the challenge of changing transit's image in the region from a business point of view. He was extremely familiar with customer orientation, particularly in an area like central Florida that was driven by service-related industry. Mr. Stuart 
recognized that Tri-County Transit did little to market itself, and was not particularly customer oriented. It was run in a traditional paramilitary style for so-called "transit dependents", similar to how most transit systems had been run for decades.

\section{"Leadership appears to be the art of getting others to do something you are convinced should be done." Vance Packard}

Mr. Stuart successfully campaigned to modify the composition of the Board and to rename the transit authority. The Board was changed significantly to reflect a more regional structure, with additional Gubernatorial appointees. The new appointees were also far less conservative than prior board members. Staff members regarded them as a rather unique collection of visionary and transit-supportive leaders. Mr. Stuart's background was in marketing, and he was a natural innovator himself. $\mathrm{He}$ wanted to completely change the mindset of the organization. The Tri-County Transit Board used to have difficulties securing a quorum, but as one former staff member noted, with Chairman Stuart, Board meetings started to become "parties" in comparison to prior years. However, Mr. Stuart felt that the agency would not reach its full potential if it continued to rely upon the management arrangement with ATE that was then in place. He believed that a more intimate, homegrown ownership of the transit system was necessary. Mr. Stuart also believed that an agency moves forward based on leadership, and he wanted to use the corporate model to accomplish this. Hence, he convinced the Board to hire not just a General Manager, but a Chief Executive Officer. He was looking for a hard charging, knowledgeable, likeable person to head the newly constituted Central Florida Regional Transportation Authority. This led to the hiring of the next prominent leader for the organization, Paul Skoutelas. Mr. Skoutelas had been the Assistant General Manager of the Port Authority of Allegheny County in Pittsburgh, Pennsylvania for a number of years. As an experienced professional from a large transit system, he knew all elements of public transit. He was still in his thirties, energetic, very personable, sharp, and articulate. $\mathrm{He}$ had also come close, but had not been selected, to serving as General Manager at other transit agencies. Mr. Stuart and the reconstituted Board saw him as someone on a career mission who could be a peer among other CEOs in the region. Mr. Skoutelas was an action-oriented manager. $\mathrm{He}$ was very outgoing and very comfortable with "selling", even though his professional experience had been in the public sector.

Mr. Stuart used his connections with the business community to open the doors for Mr. Skoutelas to meet with business leaders in the region. Mr. Stuart realized that having his new CEO meet with the business leaders in the community would reinforce the notion that the transit agency should start adopting private business practices where possible. It also provided opportunities to discuss partnerships between the private sector and the transit agency. Clearly, 
gaining access to community business leaders is a major advantage, but Mr. Skoutelas also had the right persona to take advantage of these opportunities. He had a charm and presence that complimented his thorough knowledge of the transit field. He also quickly adapted to thinking of himself more as a CEO of a major corporation than as a government manager. The title of CEO versus General Manager gave him more credibility with the business community and helped send a signal that the agency would operate more like a business. Mr. Stuart brought the creative spark, and $\mathrm{Mr}$. Skoutelas quickly signed on to the approach to do things differently.

Mr. Stuart wanted to gain attention for the new transit authority and looked for opportunities to do so. There was no money to pay for advertising campaigns, so he maximized the agency's assets to gain attention. He convinced the Board to

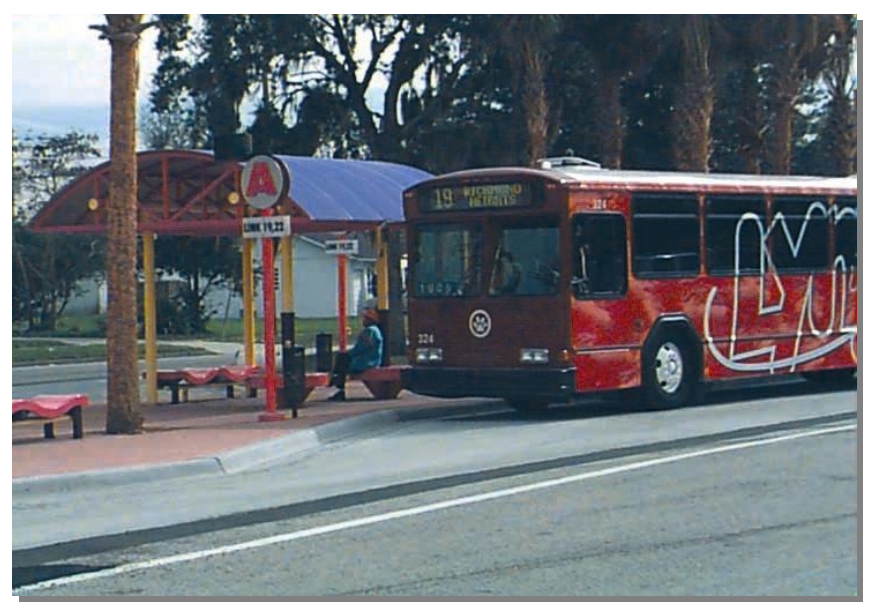

The use of bold colors on agency assets such as buses and transfer centers brought positive attention to the agency at low cost. approve painting the downtown bus terminal flamingo pink, making it visible from the nearby interstate and the high rise offices in the downtown. He also campaigned to paint the buses bright colors to capture the attention of the public. These types of actions quickly set the tone for a new way of doing business at what was to soon be called "Lynx", the new name that was derived from a public competition to rename TCT. Everything was about to change for transit in greater Orlando.

\section{Personnel and Personal Matters}

Changing an entire culture at Lynx was not going to be easy. The small, sleepy, and traditional organization was not going to change just because a new Board had new ideas. Bringing in Paul Skoutelas was a good start, but implementing change and promoting creativity was going to require new blood. This had to be done carefully, given the existence of the management contract with ATE. Some people would stay, but new managers were needed that would report to the Lynx CEO, not to a national management firm. Hence, the management contract was terminated, and Lynx went on a national search to fill managers' roles in planning, marketing, operations, and finance. 
Mr. Skoutelas was savvy enough to find someone that the Board respected to help him in the process of filling key positions. He commissioned the services of a local consultant, Winter Lantz, who worked in the field of organizational dynamics with a number of major firms in the region. He had expertise in evaluating personalities and insights into how compatible people could be with an agency's mission. Before advertising for the positions, they completed an analysis not only of Lynx's peer transit agencies, but their future peers as well. It was their intent to find the people that would get Lynx to the next level, consistent with the vision the Board had for the agency. Hence, they would need to be willing to pay their new managers at a higher level than would ordinarily be expected in an agency of Lynx's size. Mr. Skoutelas also raised the level of competence required to that which would be found in more prominent private businesses.

Mr. Lantz assisted Mr. Skoutelas with developing job descriptions and advertisements, reviewing the candidates' resumes, and grilling the candidates in interviews. Mr. Skoutelas and Mr. Lantz were deliberately looking for the most creative people possible. Most candidates needed to be knowledgeable of transit, but less traditionally structured than people in their fields. The ability to think out of the box needed to be evident in their materials, background, and their interviews. They were not looking for people to maintain existing levels of service and effort in the agency. They were looking for people who could reinvent transit in the community.

Mr. Jacobs, Mr. Skoutelas, and Mr. Lantz all knew that the service needed to be made as reliable as possible, no matter what levels of creativity were to be achieved. They also knew that Mr. Skoutelas would be spending a lot of time in the community as the visible CEO of the agency. Consequently, they decided it was important for the operations and maintenance of the agency to be overseen by someone extremely capable that was imbued with a sense of customer service who was totally trusted by $\mathrm{Mr}$. Skoutelas. They recruited Tom Rochon from Mr. Skoutelas' former transit agency in Pittsburgh. He was not only extremely professional and an excellent decision maker, but very people-oriented and open to new ideas, a necessary trait in the changing culture of Lynx.

They selected Rob Gregg to serve as the manager for planning. They had been impressed with his work at the Regional Transit Authority in Sacramento where he went beyond traditional transit planning and scheduling responsibilities. He was also very interested in the relationships between community development and transit, and with new technologies that were coming available to the industry. He was clearly an energetic, independent thinker who had been responsible for big-picture strategic planning in his previous positions. He knew transit, but was not bound to tradition. He was also very holistic in his approach to transportation, and was keenly aware of the 
opportunities for transit if it could think in multimodal terms.

\section{"Did babies die?"}

\section{Deborah Cooper,}

Marketing Director

The Creative Department (Marketing Department) was filled almost entirely with people with no knowledge of transit, all of whom came from private sector backgrounds. Most prominent was Deborah Cooper who had worked in the marketing and customer service departments in the banking industry in the Orlando area. She had no concept of how transit worked, and thought, prior to joining Lynx, that transit agencies were profit-making entities. While she understood the value of research, she felt that true creativity came from something other than market research. Good creativity develops something no one has thought of or seen, and comes from places even the creator can't predict. She was a big believer in brainstorming sessions and giving members of her staff the freedom to try new ideas. She would comfort her staff members who might have engaged in a failed effort by asking them, "Did babies die?" In short, she was always ready to try something new and attention grabbing. She was a perfect complement to the flamboyant chairman of the Board, and equally willing as he was to serve as a lightning rod to promote Lynx's visibility. Ms. Cooper realized that from a marketing and advertising perspective, Orlando (home of Disney, Universal Studios, etc.) was one of the most sophisticated markets in the country. She knew that Lynx would need to develop an equivalent style and panache to gain attention.

These key staff members in particular brought a new life force to the agency, and they in turn hired people of similar interests and natures. They valued innovative thinking and made it a prerequisite for their new hires. This collection of talent presented its own new potential problems. As former planning department staff member Bill Morris noted, "The organization started to become a bit Darwinian. Lynx was not a place for the weak of stomach." Bringing in bright, creative people with strong ideas and undeniable egos could often result in screaming matches among staff. It was in such instances that the steady, calming hand of Tom Rochon proved most valuable. Staff members were expected to passionately advocate their ideas, but Tom's decision was final and accepted by the intellectual combatants. Tom was regarded as the peacemaker, and if he became angry with the debate, everyone knew something was wrong. Fortunately, these same passionate advocates of ideas were also very fine listeners. They respected each other's capabilities, and realized that there might be something others were saying that made terrific sense. One of the principles that Mr. Skoutelas and Mr. Gregg used to help channel divergent points of view was to ask how any idea affected the mutually agreed upon mission and vision of the agency. This often helped to refine the differences in 
ideas, and get everyone working on a common path.

There was a collective understanding that Lynx was their system to promote and enhance, and if the agency gained fame, then all of them would gain individual fame, too. Everyone at the agency grew to care about the agency's image and growth potential. Staff members are not reluctant to express that their relationships became characterized by fellowship and love. Many who have since left the agency sadly reflect that they believe they will never again have as good a job in as good an environment as they had at Lynx. Part of the reason for expressing such thoughts can be attributable to outstanding leadership and dynamic staff personalities all coming together in a time and place that was receptive to change. However, the climate of enhanced creativity was also promoted by philosophies and techniques that will be discussed below.

\section{Organizational Structure, Practices, and Philosophies}

Lynx utilized a somewhat unorthodox approach to organizational structure in the early 1990s, but it was a style deliberately designed to encourage individual initiative and creativity, and to flatten the organization. Mr. Skoutelas didn't necessarily designate directors for every function in the agency right away. $\mathrm{He}$ initially referred to many on his team as "managers" rather than "directors", and let them follow their passions to take responsibility for different elements of the organization. It was a way of demonstrating that if someone had a burning desire to excel in an area, the organization was not going to stand in his or her way. Staff members could be eligible for as much as a ten percent increase if they took on more responsibilities. Key staff members were also eligible for two pay increases a year if their work warranted such reward. The agency tried as much as possible to tie performance evaluations to the organization's mission and vision. There were also small, but symbolically significant, bonuses provided at Christmas time with little handwritten notes saying "Thank you for all your hard work." This reward system was consistent with a general philosophy that Lynx would pattern itself more after the corporate world than the governmental world. Part of this philosophy came from the Board Chairman who was president of the Chamber of Commerce. But part of it was the dissatisfaction with how typical government agencies often operate and recognize (or fail to recognize) talent.

Staff members felt absolutely empowered to pursue ideas and develop proposals, and, as noted earlier, they were also encouraged to advocate their ideas passionately. There were multiple ad-hoc task forces developed to tackle issues and develop solutions. Anyone could work with anyone else in the agency. No one was pigeonholed by titles. The normal barriers of bureaucratic organizations were invisible. The one caveat behind this almost freewheeling style was that everyone had to communicate with 
each other. Mr. Skoutelas visibly demonstrated this emphasis on communication. He issued weekly memos on agency status, held weekly meetings with his managers, and monthly question and answer meetings with all employees. He would take every opportunity to celebrate any success the agency had experienced. $\mathrm{He}$ maintained an open door policy. On many mornings Mr. Skoutelas would have coffee with bus operators, mechanics, and supervisors to get to know them on a more personal basis and keep them posted on agency developments. He made it a point to engage in the practice of management by wandering around, stopping to talk with people at all levels of the organization, and, given his personal charm and genuine caring, made any employee he spoke with feel special. Given this demonstration on the part of the CEO, all employees knew they were expected to share information and not be lone wolves. Perhaps just as importantly, everyone in the organization felt closer to the leader of the program. They felt a more personal stake in the success of the agency because they were treated like real people with real feelings and ideas, not just employees that were there to perform a specific function and earn a paycheck. They had been personally asked to contribute by the agency leader, and if they had an idea on how to improve Lynx, they knew they had an audience. The managers made special efforts to be responsive to any ideas that were presented by line workers.

Just as employees needed to communicate with each other, Mr. Skoutelas and the Board realized that in such a fast-changing environment there needed to be common themes that the organization was communicating to its various staff members. This was accomplished through annual retreats that included the Board and staff managers. The retreats were facilitated by Mr. Lantz and/or Mr. Gregg, and the

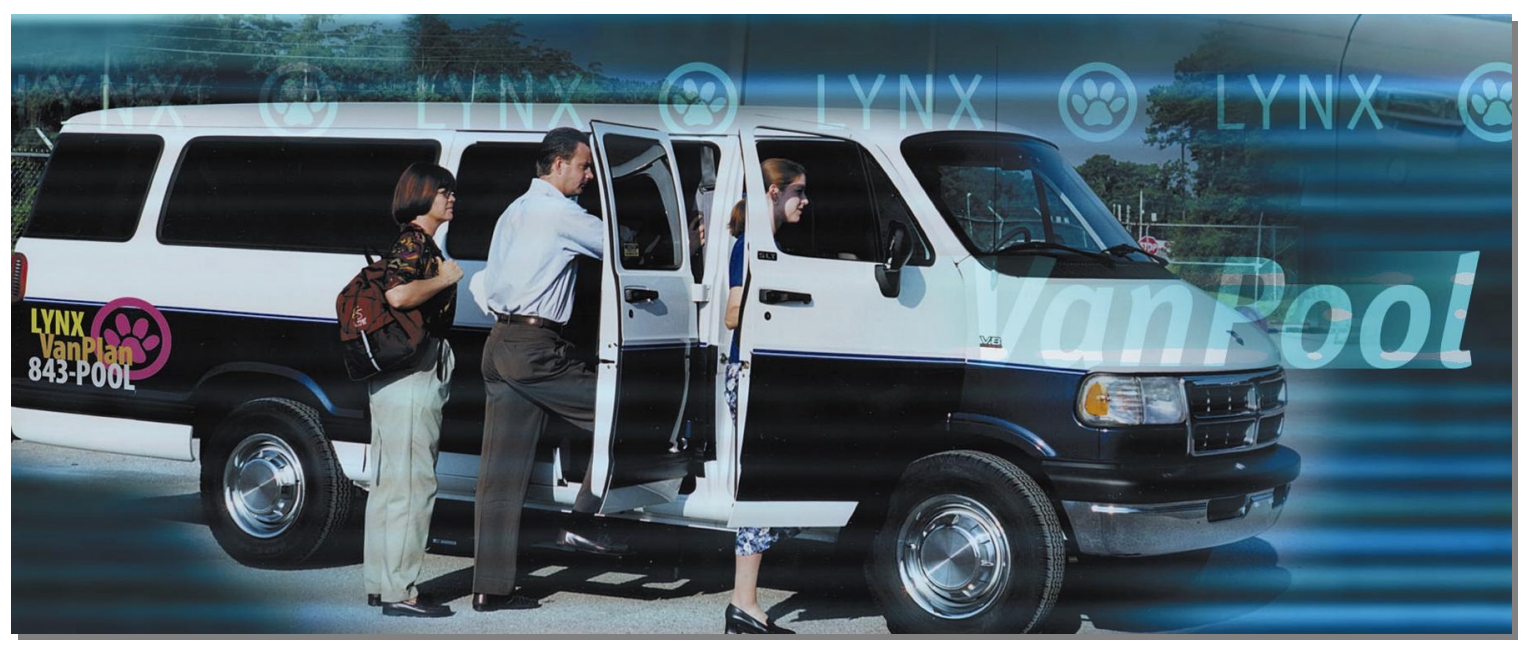

Lynx's Vanpool service is just one of many non-traditional transit agency programs that reflect the agency's desire to serve as a true mobility manager in the region. 
atmosphere was deliberately relaxed, loose, and comfortable. In short, they were fun, but very productive. During these retreats the participants would develop their vision and mission statements for long-term success, as well as a business plan for the upcoming year. The following vision statement was adopted to guide the agency's development:

"To become recognized as a world-class leader in providing the full array of transportation services in Central Florida."

The adopted mission statement provided further clarity for Lynx employees and the greater Orlando region:

"To create a comprehensive transportation system for residents and visitors that offered quality customer service in a cost effective manner."

These statements sent the message that Lynx wanted to earn the status of other worldclass public and private entities in the region. They also sent the message that Lynx wanted to be more than just "the bus company". It wanted to contribute to all the mobility needs in the region. Finally, it emphasized customer service and efficiency. In addition, Lynx adopted the slogan "Moving to be America's Best." Clearly, the new transit agency in town set high standards, and the leaders in charge felt they had the opportunity and policy support to accomplish these goals. The agency moved in the direction of being mobility managers, taking on responsibilities for the area's Commuter Assistance Program offering assistance in creating vanpools, car pools, and school pools, and even offering a "Highway Helper" program for brokendown motorists. Lynx aggressively pursued grants for new and flexible forms of transit, resulting in the nation's first downtown Bus Rapid Transit system and other flexible BRT applications in suburbs. The agency also gained renown for leadership in developing manuals and standards for transit oriented development and transit customer amenities and facilities.

\section{"Being customer focused means you have a retail mindset. You are competing for customers and absolutely thrilled to have them." Ernie Kelly Assistant Marketing Manager}

Lynx leaders wanted to reinvent transit in central Florida. One thing the Board members and new key staff recognized was that Tri-County Transit had not been truly customer-oriented. It had fallen into the routine of being more operations-oriented, driven by internal decisions on schedules and routes, and not at all engaged with the community. Lynx managers decided that one of their fundamental missions would be to ensure that they were customer-focused and that they incorporated community values in their approach to service. This message was repeated again and again by Mr. Skoutelas at group meetings and meetings with individuals. As Creative 
Department staff member Michelle Ranelli noted, "Being customer-focused means that the customer is your first priority. Everything you do is done on behalf of the customer instead of on behalf of some internal interests." Ernie Kelly, also of the Creative Department added, " Being customer-focused means you have a retail mindset. You don't assume you are a monopoly or utility. You never dare to use the phrase 'captive passenger'. You are competing for customers and you are absolutely thrilled to have them."

When it came to customer orientation, Lynx talked the talk and walked the walk. Although it cost many tens of thousands of dollars, the agency had all of its bus operators complete the Canadian-based "Transit Ambassador" program, designed to train bus operators in how to best serve customers, make every passenger's trip as pleasant as possible, and serve as good-will ambassadors for the agency. The agency provided diversity training as well, vital in a rapidly growing area that also hosted people from over 100 countries on a routine basis. This not only furthered the agency's interests in gaining friends in the community, but it was also highly appreciated by the union and its members. This helped to build trust between managers and union officials, and encouraged union members to buy into the customer-oriented, community-based approach to providing transit. Union officials believed that the agency had their best interests at heart, and were therefore willing to work with the agency on identifying efficiencies where possible.

This corporate, retail approach was effectively transmitted and accepted throughout the agency. Even members of the service line, often the most overlooked employees at a transit agency, knew that they were doing what they did because it was important to customers and for the agency's growth.

The Lynx team was clearly sending out the message that they wanted to partner with as many entities as possible in the community, whether it was school boards, universities, downtown development authorities, social service agencies, planning agencies, chambers of commerce, major employers, non-profit organizations, other governmental organizations, and more. Lynx worked with private shopping centers to develop "Super Stops" on private property that served as transfer points for transit passengers. The joint promotions they helped support were in areas not normally associated with local transit systems, such as being primary sponsors of a jazz festival and a museum exhibit. By actively pursuing partnerships, they opened up entirely new opportunities for creatively spreading the message about transit. In essence, they tried to associate themselves with every positive thing going on in the community, and benefited from such positive associations. 


\section{"People like to be sold to- They like to be wanted." \\ Deborah Cooper, \\ Marketing Manager}

In essence, Lynx was selling - not only to its customers, but also to its own employees and to the community. As Deborah Cooper stated, "People like to be sold to - they like to be wanted." The agency leaders knew that if they wanted to sell Lynx to a growing customer base, the product had to be good. Hence, they worked hard on internal marketing with their own staff to secure the maximum effort from every employee to provide a quality service. Lynx would also do internal casting calls, using their own employees in advertisements and commercials. This technique made employees feel a greater sense of ownership and responsibility. If the community was going to invest more in Lynx, the agency would have to show it was providing quality service that was meeting various needs in the community and demonstrate their ability to be efficient. Hence, they took part in community events and organizations, and found dozens of ways to demonstrate their cost-effectiveness and good stewardship of funds. If they were going to become truly world class, they were going to need support for high performance transit services. Hence, they needed to spread the transit message whenever and wherever they could. They needed to get attention in positive ways. Lynx staff was on a mission to penetrate the community. This led to incredibly creative methods of ingratiating the agency with the community. Mr. Skoutelas was a member of numerous local boards that enabled him to stay in touch with agencies that were providing valuable services to different components of the community. He insisted that his staff members also become members of different

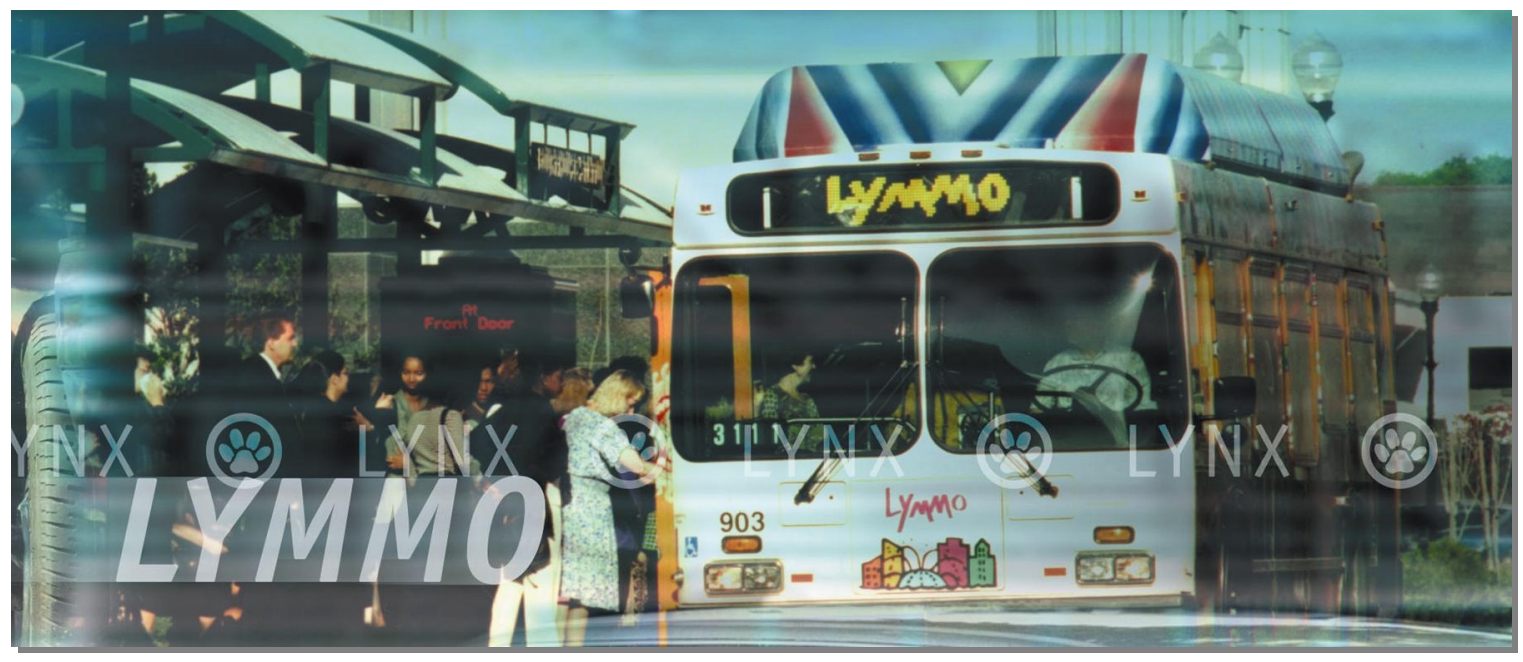

Lynx's "Lymmo" Service features all elements of Advanced Public Transportation Systems and is the only Bus Rapid Transit service in the country operating exclusively in a downtown area. 
local task forces or agencies. All of the key members of the Lynx staff were participants in "Leadership Orlando" programs. The standard gag was that whenever two or more people congregated, it was vital for a representative of Lynx to spread the message of the value of transit to the community.

Staff members and the Board had come to develop a new "Lynx-like" culture. To different staff members, "Lynx-like" meant being bold, different, colorful, unlimited, beneficial, corporate, and, perhaps most significantly, fun! Humor was a huge element of the working environment at Lynx. "Let's have some fun with it," was an often-heard suggestion from Mr. Skoutelas. People worked hard at Lynx, possibly harder than they had ever worked elsewhere, but they knew how to laugh, and always looked for opportunities for the acceptably absurd. Lynx staff developed internal criteria for what was within acceptable limits. There was an informal cost-benefit analysis done before each new idea; if the benefits of success were much greater than the potential loss that could occur, then the agency tried it. Failure was acceptable, but new ideas were carefully considered before implementing them.

Staff members were on a mission at Lynx. Some new employees might be skeptical of how unbelievably sunny the staff was. But as Ernie Kelly said, "It was like seeing employees at Disneyland. This was the Lynx culture, and you either bought into it or you left." The agency invested time and effort into nurturing creativity. The agency developed awards for creativity and innovation as well as customer service to help reinforce the high regard for such virtues. It would have retreats where transit was never discussed. Instead, they would focus on methods of creativity being used in the corporate world, and participate in such things as Hermann Brain Dominance Theory exercises designed to get participants to use their "whole brain". Mr. Gregg worked hard to get everyone to participate, "To get everybody naked" as former Operations manager Dennis Dee described. It was in such sessions that staff members came to name the bus routes "Links" and to develop "Catitude" awards, among many other things. It was through such exercises, and many others where Lynx staff operated on a more personal basis that a genuine sense of love and friendships that would last for a lifetime were formed.

\section{Notable Results}

In both 1995 and 1997, Lynx won APTA's award as "Best System of its Size". In contrast to the old TCT experience, surveys taken in the late 1990's showed that 90 percent of all respondents knew that Lynx was the regional provider of public transit services. Lynx absolutely transformed the relationship between transit and the community in central Florida. In less than 10 years, it grew from an 80 bus system carrying less than 10 million passengers a year, to a system with over 200 buses that was carrying over $22,000,000$ passengers a 
year. Lynx helped redefine the meaning of marketing in the transit industry. And they came within one elected official's vote of building a half-billion dollar Light Rail system in the region, which they are still trying to accomplish.

"Don't let it be forgot that once there was a spot for one brief shining moment that was known as Camelot."

Alan Jay Lerner 


\section{SUMMARY AND CONCLUSIONS}

This project was undertaken to try to identify the practices and philosophies that contributed to the creativity that was present in four particularly innovative transit agencies in the hopes that the lessons learned can be utilized by other transit agencies. Clearly, the environment in which each of the four transit agencies operates played a significant role in their creative natures. In two cases (Centro and SunLine), the agencies were in dire budgetary straits that required them to find as many opportunities as they could to generate new revenue or reduce costs. In one case (Lynx), a rapidly expanding community in need of additional transportation services provided the opportunity for the transit agency to try to gain market share and convince the community they were worthy of greater investment. At Citifare, the Board reflected the conservative nature of the community and region and expected a business-like, efficient operation that was as self-reliant as possible. Interestingly, in three of the four case studies, the regions in which the transit agencies operate are quite conservative in nature. However, environments and local circumstances are unique to each area, and not transferable to other transit agencies.

In addition, leadership and personalities played a major role in the level of creativity at the various agencies. Some of the leaders were flamboyant, while others were either politically skilled, charismatic, blessed with business acumen, or phenomenal team builders. Interestingly, the strengths of the various leaders varied considerably. But as is the case with environment, individual personalities are not replicable or easily transferable to other transit agencies.

Fortunately, there were a number of practices and philosophies that seemed to be prevalent in the four transit agencies that were visited. These practices and philosophies might well be transferable to other transit agencies, depending on their own unique environment, circumstances, and personalities. The four agencies that were reviewed demonstrated a propensity for the following:

- They operate with business principles and an entrepreneurial spirit

- They enjoy experiments

- They have a broad self-image

- They have a passion for adding value to their community

- They believe in bringing in new blood

- They believe in, and support, training and professional development

- They believe in, and practice, teamwork

- They have very positive, can-do attitudes

- They have a firm belief in the importance of communication

- They realize the value of relationships 
These organizational practices and philosophies are what can help any transit agency to think out of the box. The key elements of each one of these factors are summarized below.

\section{They operate with business principles and an entrepreneurial spirit}

Employees at the four transit agencies were results oriented, not process oriented. There is an understanding that even the simple things must be done well, or they would not be allowed to try riskier things. Many of the key staff came from private sector backgrounds, thought in "retail" terms, and recognized the opportunities transit systems had to sell their services, knowledge, programs, or access to facilities, equipment, or passengers. Similarly, they understood the true meaning of customer service. They directed their energies to their passengers and community, and avoided becoming selfcentered, internally oriented bureaucracies. Employees who demonstrated outstanding customer service were visibly rewarded. They understood the value of market research and used it to identify their opportunities to gain ridership, friends, and partners. Employees were challenged, empowered, and supported to take reasonable risks. Leaders "provided cover" for their staff, pushed them to try new things, and tolerated occasional failure as an acceptable risk. This external focus on customers, markets, and opportunities virtually requires thinking outside of the box.

\section{They enjoy experiments}

Leaders in the four agencies believed in the inherent value of experimentation. They would ask "Why can't we," and "Lets try before someone else beats us to it." Nothing was off limits. They aggressively pursued discretionary grants that allowed for pilot programs. They held high standards, but believed in having fun. They worried more about missing opportunities than failing in a reasonable risk. Not only might they find better ways of doing things; they understood that experimentation gets most people at the agency interested and excited. Employees find themselves in a learning environment that makes it fun to come to work, an environment in which they can hardly help but get involved and offer new ideas as they learn.

\section{They have a broad self-image}

Staff members at all four of the agencies did not want to be referred to as employees of the "bus company". They regarded themselves as mobility managers for their region, who not only thought in multimodal terms, but in comprehensive terms that took into account the relationships between land use and transportation and how transit could help the regional economy. They believed their self-image and their ability to gain partners could suffer if they were regarded 
as only a social service agency for the disenfranchised. People were genuinely excited about what they could be. They wanted to change communities and change peoples lives. As one said, "We are involved in transformation, not just transportation".

\section{They have a passion for adding value to their communities}

Managers at the transit agencies had done their math. They realized that only a small minority of people in their communities actually use their basic service, so they needed to find ways to make their agency more relevant to the majority of people who did not. They pushed their staff to find things that their agency has, does, or could do that might somehow help the broader community. They had a burning desire to be regarded as a true public benefit corporation, as a regional asset instead of a burden. Hence, they looked for ways to ingratiate themselves to the community, even if it was in ways that have little to do with transit per se. In addition, they tried to operate in ways that were consistent and supportive of community values. For instance, Orlando is a family-oriented community. When Lynx began their famous illustrated bus campaign, they made sure not to illustrate any buses with products that couldn't be used by a minor.

\section{They believe in bringing in new blood}

Managers at these creative transit agencies tended to come from diverse backgrounds, and there was an unwritten policy that having such diversity was healthy for the organization. There was a particular interest in bringing in people with private sector experience, who approached the concept of problems and opportunities differently than traditional public sector employees. They wanted to bring new perspectives to their agency. When hiring new employees, the managers were as interested in the person as they were in that person's specific skills. They wanted "people persons" with good interpersonal and communication skills. These qualities allowed for greater exchange of ideas among staff. They tended to hire people that they thought would be fun to work with. They also looked for leadership aptitude in their candidates for new positions, valuing their ability to exercise independent thought. As one manager noted, "My job is to hire the next president of the company".

\section{They believe in, and support, training and professional development}

These agencies truly believed that their people and their peoples' indispensable energy were their most important assets. They encouraged their staff to join APTA and Transportation Research Board committees, and to be involved in their state 
transit associations. They encouraged employees to become familiar with the Internet, to subscribe to professional journals, visit peer transit properties, and stay in touch with professional counterparts around the country by phone and email. The agencies also encouraged and supported their staff members to join local Leadership programs as well as Leadership APTA. The agencies realized that more interaction with other professionals around the country would expose their employees to more ideas and cause them to think in broader terms.

\section{They believe in, and practice, teamwork}

While the agencies valued independent thought, they also recognized the added value that teamwork can provide to the creative process. All of the agencies participated in retreats and brainstorming sessions where they often used facilitators that helped approach subjects in new and untried ways. There was considerable evidence of the use of cross-functional teams to address a variety of agency issues, where ideas could be cross-fertilized to create new approaches to problems. It was not unusual for the agencies to utilize techniques such as the Meyers-Briggs Personality Profiles to help management teams get to know and understand each other better, in order to facilitate more positive communications and exchange of ideas. They believed it was important to hire people who were tolerant of other people and new ideas. It was also common for the agencies to utilize group assessments of new candidates for key positions, where a representative from each one of the major functional areas of the agency would participate on the panel to select a new manager. In short, "organizational silos" were minimized, and everyone was accountable for thinking in terms broader than their specific function.

\section{They have very positive, can-do attitudes}

Employees at these agencies had a very strong sense of mission that was bolstered by meaningful organizational mission and vision statements. These statements promoted solid core values and included references to creativity, maximizing investments, building relationships, partnering, etc. These statements were challenging, but also implied expectations for employees to go the extra mile. One would never hear the phrase, "That's not my job" at these agencies. Everyone had a sense of ownership and responsibility for the entire agency and its image, and once someone became aware of a problem, they owned it until it was solved. They relished the image of being problem solvers, not problem managers.

\section{They have a firm belief in the importance of communication}

All of the agencies went to extensive efforts to practice thorough and frequent 
communication. There was considerable effort made to have productive meetings among staff to ensure a cross-fertilization of ideas, and to develop consensus for multiple projects. When hiring new personnel, the agencies stressed selecting people with good communication skills. They realized that you cannot motivate unless you communicate, and they took every opportunity to share information on agency status with all employees through newsletters, formal and informal meetings, and management by walking around. Agency managers understood that communicating with the media can result in positive coverage that helps create greater Board support of agency initiatives. The managers believed in bombarding their boards with information. They understood that communication helps build trust - most board members don't like surprises. More importantly, when trust is established, then you are allowed to experiment and try new things. Boards will tend to support taking a few risks as long as they are kept informed.

\section{They realize the value of relationships}

Managers at the agencies understood the value in getting to know other people they work with as people, not just as professional associates. It was important for them to attend social functions to personalize their relationships with those they worked with. As one manager noted when stating why he attends social functions with his board, "They are less likely to hate me if they know me." He knew they would feel more comfortable with him, which would again make it easier to get consent to try something new. The managers did not want their staff to be a bureaucratic group of strangers to other elements of the community. They also insisted that their staff members be members of community organizations. That practice kept the staff plugged into what was important in the community, and gave them opportunities to establish new partnerships and programs. In short, they realized a simple truth - what goes around, comes around. Others are usually only going to care about you at the same level as you care about them. If you can show you care about others, they are more likely to return the favor and look for ways to work with you. This opened doors for the agencies to allow them to work on non-traditional projects that helped improve the image of transit in the community.

If there is a common theme among these factors, it might be identified as the need for individuals at the agencies, and the agencies as a whole, to think more externally and avoid the trap of routine internal orientation. The techniques listed above all require working with others and working on nontraditional matters. It is clearly helpful to have staff members who are naturally curious and creative. However, the agencies can do many things that will foster creativity by being entrepreneurial, interdependent, customer and community-oriented, communicative, experimental, and personalized. While the specific experiences of the four agencies might not be able to be 
duplicated elsewhere, the techniques they employed to foster creativity can help other agencies find their own special experiences. 


\section{APPENDIX A - SITE VISITS AND CONTACTS}

\section{Central New York Regional} Transportation Authority (Centro)

Joe Calabrese, President/General Manager

John Clare, Vice President of

Administration

Richard Landerkin, Director of Transit Planning

Linda McKeown, Director of Paratransit

John Renock, Vice President of Operations

Dave Ristau, Director of Marketing

Steve Share, Chief Financial Officer

Craig Williams, Director of Human Resources

\section{Regional Transportation Commission of Washoe County (Citifare)}

Celia Kupersmith, Executive Director

Michelle Gordon, Administrative Services Manager

Cassandra Harrison, Operations Director

Roger Hanson, Transit Planner

Joe Jackson, Maintenance Director (ATE)

Greg Krause, Planning Manager

Derek Morse, Engineering Manager

Michael Steele, Transportation Manager (ATE)

Thomas Taelour, Financial Manager

Sharon Wilson, Human Resources Administrator

\section{SunLine Transit Agency}

Richard Cromwell, III, General Manager

Bill Clapper, Director of Sunline Services Group

Tracy Daly, Deputy General

Manager/Director of Resource

Development

Sarah DeGrandi, Chair of SunLine Transit and Council Member

George Earl, Director of Maintenance

Dennis Gilman, Deputy General Manager for Administration

Ray Grosclaude, Director of Transportation

Dennis Guinaw, Director of Special Services

Kim Malcolm-Valente, Director of Human Resources

Richard Samuels, Bus Operator/President, ATU Local 1277

\section{Central Florida Regional Transportation Authority (Lynx)}

Paul Skoutelas, Chief Executive Officer

Deborah Cooper, Director of Marketing and Community Affairs

Dennis Dee, Operations Manager

Rob Gregg, Director of Planning

Ernie Kelly, Marketing and Community Affairs

Bill Morris, Planning and Development

Michelle Ranalli, Marketing and Community Affairs

Bill Schneeman, Director of Operation 


\section{Appendix B - Examples of Techniques Utilized by the Case Study Transit Agencies that Generate New Revenue or Reduce Cost}

\section{Regional Transportation Commission of Washoe County (Citifare)}

RTC takes a strong stand against potentially weak or fraudulent claims against the agency, even if the attorney fees cost more than the claim. The legal community has effectively received this message and the number of claims has gone down substantially from prior years, providing short and long-term savings.

RTC saved approximately $\$ 3.7$ million in insurance costs by implementing a Self-Insured Retention program in which RTC would pay any loss up to $\$ 50,000$ and would contract for insurance coverage from that amount up to $\$ 10$ million.

RTC tripled its revenues from the sale of space on buses for advertising by bringing the advertising function in-house versus contracting for such services with national firms. In addition to increasing revenues, they also established closer relationships with local private businesses, rather than one-time customers, that worked more closely with the transit agency to promote the utilization of transit.

RTC replaced existing concrete/wood bus stop benches with metal grate benches that are far less subject to graffiti, thereby reducing maintenance costs. The agency also stopped hand washing bus shelter panels, and instead utilizes portable power washing equipment, reducing the time necessary to keep shelters clean.

RTC's contractor (ATE) developed a "cafeteria plan" approach for run cutting, in which drivers construct their own work weeks from a list of available pieces of work and from a list of any days off. The agency saved approximately $\$ 300,000$ through the elimination of premiums and break time, while the drivers are happier since they have the opportunity to structure their own week and time off.

RTC works in partnership with Washoe County to purchase fuel and to invest funds of the agency, thereby maximizing savings and return on investment, and eliminating the need for separate staff to perform these functions.

RTC retains control of all physical assets (buses, vans, facilities, etc.) and contracts for all fixed route and paratransit services, thereby generating the most competitive proposals possible to help reduce operating costs.

The RTO is the transit agency, the Metropolitan Planning Organization, and the designer of local roads in the region. This consolidation of authority helps reduce redundancy of local staff and keep costs down. 


\section{Central New York Regional Transportation Authority (Centro)}

Passengers who purchase 10-pack tokens or monthly passes also receive coupon booklets each month for discounts at local businesses. The private companies produce the coupons after Centro provides specifications. Each vendor also pays Centro $\$ 500$ per month for the right to access the agency's passengers through this coupon program.

Budgetary cutbacks resulted in Centro having spare space in its facilities. All vacant space in its administrative offices, as well as bus maintenance bays and storage areas were leased, producing annual revenue of $\$ 40,000$.

Centro leases its 22 over-the-road coaches to private charter bus companies that realize capital savings by using Centro's equipment during off-peak, weekends, and evenings for infrequent events that require more capacity. This results in a win-win solution for public and private interests, and generates over $\$ 60,000$ in revenue to Centro annually.

Centro, with 20 Ford paratransit vans, has become an authorized Ford warranty center and performs the warranty repairs and gets paid by Ford in a manner resulting in profits for the agency. Their designation as a warranty dealer also allows them to compete for warranty work on other Ford vehicles owned by social service agencies that also provide paratransit service with vehicles that have been purchased through a state Government Services Agreement contract.

Centro negotiated a deal with AT\&T for the installation of telephones in bus shelters. Centro receives $\$ 100$ per month per phone, plus a percentage of revenue. In addition, the phones are programmed to allow callers to dial "*BUS" for a free connection to Centro's customer service information center.

Centro partnered with Niagara Mohawk Utilities for the installation of a CNG fueling facility. State and federal grants paid for 90 percent of the fueling facility, with Niagara Mohawk paying the 10 percent local share of $\$ 350,000$. The utility company paid the local share difference between the cost of 20 conventional diesel fuel buses and a similar number of CNG buses $(\$ 500,000)$. In exchange, Centro purchases fuel from Niagara Mohawk. Centro also sells CNG to retail customers and retains a portion of the profits, and is also looking into selling energy credits to companies that are in violation of air quality standards.

Centro contracts with two universities to provide service in a manner that generates new revenues and riders. In one contract, the agency receives fixed revenue per vehicle hour that more than covers their costs. In another contract, Centro provides service that goes through areas of the city as well as the campus, and receives revenue from the university based on estimated boardings, while operating open-door service throughout.

\section{SunLine Transit Agency}

The combining of three paratransit subscription routes into one community route resulted in savings of $\$ 40,000$ a year. The use of taxis for off-peak times for ADA service resulted in savings of up to $\$ 10,000$ per year. SunLine realigned their bus routes to a modified pulse system. This allowed the agency to provide almost identical service, yet dramatically reduce hours and miles with one trunk line and a series of feeder routes. 
The opening of a new operations base resulted in substantial operating savings to the agency with a reduction of hours and deadhead miles.

SunLine uses a disabled intern to staff the paratransit reservation desk that costs the agency nothing and results in savings of close to $\$ 18,000$ a year.

SunLine shares equipment owned by private non-profit agencies resulting in a capital savings of $\$ 220,000$ over five years, and also sells maintenance service to non-profit agencies with a yearly savings of up to $\$ 7,500$. The also rent unused space to community agencies producing revenue of $\$ 10,000$ per year.

SunLine administers a self-insured program and takes the risk of liability for all claims up to $\$ 125,000$. This program, coupled with extensive emphasis on safety, has resulted in a $\$ 75,000$ annual savings to the agency over previous insurance premiums.

SunLine sells CNG fuel to other municipal fleets through a public/private partnership in which a mobile $\mathrm{CNG}$ compressor delivers the fuel to remote sites throughout the community. CNG fuel is also sold at stationary sites that are serviced by SunLine staff. SunLine claims that using CNG rather than diesel fuel has reduced their cost per mile by $\$ .20$ and reduced their miles between road calls to 30,000 .

SunLine has established a "SunLine Services Group" that allows this transit agency to offer nontraditional community services that no other level of government provides in the region. These services are provided through the utilization of part-time bus operators who are happy to have the extra work, and helps SunLine retain them as employees before they become full-time bus operators. They provide services including street sweeping, graffiti removal, changing streetlights, watering plants at intersections, traffic signal maintenance, building levees for flood control districts, and providing emergency lights and generators at major community events. Revenue collected from these services more than made up for the loss of $\$ 400,000$ in annual operating revenue from the federal government.

\section{Central Florida Regional Transportation Authority (Lynx)}

Lynx established a number of partnerships with public and private entities that resulted in substantial operating revenues for the agency that more than paid for the service and allowed the agency to redesign routes to generate more ridership. The City of Orlando pays Lynx over $\$ 52,000$ annually for shuttle services provided from downtown to the Centroplex, which includes arenas and auditoriums. The Orlando Downtown Development Board sponsors the "Freebie" (now the "Lymmo") and pays over $\$ 500,000$ annually for a downtown circulator that runs every five minutes from 6:20 a.m. to 7:00 p.m. The developer of the Seminole Town Center contributes $\$ 20,000$ (and the City of Sanford matches that amount) to pay for the extension of a regional route to the center.

Lynx was a world leader in the "illustrated bus" program. Rather than considering the advertising program as a by-product, it became an active division of the agency that generated major revenues. Lynx made an investment in a Macintosh System and hired artists to both design and paint the buses. There are stringent quality control standards and all artwork must be agreed to by the client and Lynx. This program resulted in $\$ 3$ million annually in cash and trade. 
Lynx sells its waste oil for three to four cents a gallon to offset the cost of disposal of hazardous wastes, saving over $\$ 1,300$ annually. Lynx also conducts oil analysis, sending samples to Chicago to determine if fuel has slipped into the crankcase. The agency believes it has saved over $\$ 100,000$ annually by avoiding the need to rebuild engines.

Lynx utilizes "toll credits" rather than cash to match capital grants, enabling the agency to fund capital projects at $100 \%$ federal funding. This has saved the agency over $\$ 2$ million dollars annually.

A mentor program was established to help new bus operators adjust to their new work world. This program, which cost virtually nothing to implement, resulted in reducing turnover among first-year bus operators from fifty percent to eight percent. This helped reduce costs due to absenteeism and turnover by over $\$ 200,000$ annually. 